\title{
The Competitive Effects of Risk-Based Bank Capital Regulation: An Example from U.S. Mortgage Markets
}

\author{
Diana Hancock, * Andreas Lehnert, Wayne Passmore, and Shane M. Sherlund \\ Federal Reserve Board ${ }^{\dagger}$
}

August 2006

\begin{abstract}
Basel II bank capital regulations are designed to be substantially more risk sensitive than the current regulations. In the United States, only the largest banks would be required to adopt Basel II; other depositories could choose to adopt such standards or to remain under the Basel I capital standards. We consider possible effects of this two-pronged or "bifurcated" approach on the market for residential mortgages. Specifically, we analyze whether those institutions that adopt Basel II will enjoy lower costs than nonadopters and whether they have an incentive to retain mortgages in their own portfolios. We find that (1) despite the large differences in regulatory capital requirements between adopters and nonadopters, it is unlikely that there will be any measurable effect of Basel II implementation on most mortgage rates and, consequently, any direct impact on the competition between adopters and nonadopters for originating or holding residential mortgages; (2) the most significant competitive impact may be felt among mortgage securitizers; and (3) adopters might have increased profits from some mortgages relative to nonadopters because they will capture some of the deadweight losses that occur under the current regulatory regime, but nonadopters would likely retain their market shares.
\end{abstract}

JEL Classification Codes: G18, G21

Keywords: bank capital regulation, mortgages, market competition, government-sponsored enterprises, GSEs

† The opinions, analysis, and conclusions of this paper are solely the authors' and do not necessarily reflect those of the Board of Governors of the Federal Reserve System. We thank Tom Boemio and Brad Case for their assistance with understanding Basel I and Basel II capital standards, Gerhard Fries, Arthur Kennickell, and Kevin Moore for their helpful suggestions on using the Survey of Consumer Finances, Cathy Gessert, Jonathan Hershaff, Reid Dorsey-Palmateer, and Laura Kawano for their excellent research assistance, and Glenn Canner, Ellen Dykes, Ed Ettin, Michael Gibson, David Jones, Jonathan Jones, Paul Kupiec, Myron Kwast, David Malmquist, and Steve Oliner for their insightful comments and suggestions.

* Corresponding author address: Diana Hancock, Mail Stop \#153, Board of Governors of the Federal Reserve System, Washington, DC 20551; e-mail: Diana.Hancock@frb.gov; phone: (202) 452-3019; fax: (202) 452-5295. 


\section{Introduction}

In this paper we study the potential effect of the transition from Basel I to Basel II, one of the largest changes to U.S. bank capital regulation, on the market for residential mortgages, one of the largest loan markets. We develop a theoretical model that allows us to characterize how changing capital regulations might affect equilibrium outcomes in the primary and secondary markets: We then apply this model to the residential mortgage market using various data sources. Broadly speaking, we find that bank capital requirements do not significantly affect equilibrium outcomes in the mortgage market because market participants already effectively manage their regulatory capital requirements under the current regime using secondary markets. However, the switch to the more risk-sensitive Basel II regulations has the potential to heighten competition between intermediaries (e.g., banks) and securitizers.

In 2012, U.S. depository institutions will begin to operate under a so-called bifurcated capital regime: ${ }^{1}$ the larger institutions will likely be subject to a new set of capital rules (Basel II) and all others will operate under the current capital rules, which are based on Basel I. ${ }^{2}$ Under the U.S. proposal, depositories with consolidated banking assets of $\$ 250$ billion or more or foreign exposures of $\$ 10$ billion or more are required to adopt the advanced approaches of Basel II. Certain other depositories may choose to adopt Basel II or remain under the current requirements. All other U.S. depositories are to remain under the current capital regime. ${ }^{3}$

The greater risk sensitivity of Basel II is expected to lower the regulatory capital requirements on the credit risk of most residential first-lien mortgages, although it may also raise them on the riskiest mortgages. The depositories that remain under the current capital regime, which imposes a 4 percent regulatory capital charge on all residential mortgages regardless of risk, are thus expected to face higher regulatory capital requirements on their residential mortgage portfolios than those that Basel II adopters would face. The difference in capital treatment has been criticized as placing those who do not adopt Basel II at a competitive disadvantage in the residential mortgage credit market. ${ }^{4}$

The bifurcated approach will test the effect of bank capital regulations. If the regulations affect mortgage market outcomes, the lower regulatory capital requirements under Basel II may result in a cost advantage for the institutions that adopt them. The cost advantage, in turn, may translate into (1) a pricing advantage for adopters in mortgage markets, who may then increase their market share of originations at the expense of nonadopters, or (2) an increase in the adopters' profits that would give them greater competitive strength in all credit markets. In addition, some analysts have reasoned that, regardless of the effect on mortgage interest rates, the greater risk sensitivity in Basel II capital requirements for residential mortgages could provide incentives for adopters either (1) to retain in their own portfolios mortgages that they now 
securitize, or (2) to outbid the GSEs and provide credit risk protection on low-risk mortgages in securitization markets. ${ }^{5}$

Our research, however, does not support the view that bank capital requirements influence equilibrium outcomes in the mortgage market. First, we find that Basel II implementation is unlikely to have any measurable effect on mortgage rates paid by borrowers and, consequently, any direct effect on the competition between adopters and nonadopters for originating or holding residential mortgages. The market has already effectively adjusted to a lower regulatory capital charge by using GSE guarantees and other forms of securitization and by blending higher- and lower-risk mortgage portfolios to arbitrage the current one-size-fits-all capital regulations. We show that current regulations require much more capital backing for most residential mortgages than secondary market investors require, providing a powerful incentive for banks to sell mortgages into the secondary market. (However, as we discuss in section 3, a simple comparison of capital charges faced by depositories and securitizers is not enough to determine the extent of such regulatory capital arbitrage, because frictions such as adverse selection will limit the ability of market participants to trade credit risk.)

Second, the most significant competitive effect might be the pressure that adopters put on GSEs to lower their guarantee fee for prime mortgages. We find that almost 90 percent of prime mortgages might have a lower regulatory capital charge for adopters than is currently imposed on GSEs.

Third, adopters of the Basel II (Advanced Internal Ratings Based) approach nevertheless may increase their profits from some mortgages relative to nonadopters because they will capture some of the deadweight losses that occur under the current regulations imposed on depositories and on securitizers. ${ }^{6}$ However, only relatively few mortgages would likely be affected, and mortgage rates would remain

unchanged, particularly in the near-term. Importantly, the increased profits for adopters would not be direct income transfers from nonadopters of the new framework; instead, the adopters would capture the deadweight losses. ${ }^{7}$

The balance of this paper provides theoretical and empirical support for these conclusions. Section 2 describes the current (Basel I-based) and proposed (Basel II) capital standards for mortgages. Section 3 provides our conceptual framework for analyzing the potential competitive effects of the bifurcated application of Basel II in the United States. Section 4 analyzes the effects of implementing Basel II in this manner on various segments of the U.S. mortgage market. Section 5 concludes with an evaluation of the potential competitive effects among depositories and GSEs.

\section{Economic, Regulatory, and Prudent Capital}

Regulatory capital requirements are said to be "binding” only if a depository institution is required to hold more capital than the market would require. In this section, we define three concepts of capital: (1) economic capital: allocations used by depositories to price, extend, sell, or securitize 
mortgage credits; (2) regulatory capital: minimum standards demanded by regulators to back mortgage assets under the current and under proposed regulatory frameworks (we will focus in this paper on those regulations related to an asset's risk, or risk-based capital); and (3) market-determined or prudent capital: amounts needed to satisfy counterparties and rating agencies; that is, an amount of capital that includes a cushion above model-determined economic capital to reflect modeling uncertainty and expected losses.

\subsection{Economic Capital}

Economic capital is determined so that the probability that unexpected credit losses will exhaust economic capital is less than some targeted level (the target insolvency rate). For example, the level of economic capital may be set to achieve a particular estimated probability that unexpected credit losses will exceed it. A depository typically chooses a target insolvency rate that is consistent with the credit rating it desires for its liabilities: For example, if this desired rating is AA, the target insolvency rate might be set at the historical default rate for AA-rated corporate bonds, which is about 0.03 percent.

Large depositories typically have internal systems for allocating economic capital that embody either an implicit or an explicit estimate of the probability density function (PDF) of credit losses for their credit portfolio or for subportfolios. Although the precise definitions of credit loss tend to vary across depositories depending on the model they use for measuring credit risk, risky portfolios are those with a PDF that has a relatively long, fat tail (that is, those having a relatively high likelihood that losses will be substantially higher than mean, or expected, losses). For internal decision making and internal capital allocation, depositories generally collapse the estimated PDF for a subportfolio or a portfolio into a single measure, the economic capital allocation for credit risk (Jones and Mingo, 1999).

\subsection{Regulatory Capital}

Regulators set the capital required to back assets in a variety of ways; in this paper we focus on risk-based regulatory capital standards; that is, regulations that require more capital to back higher-risk assets. Other capital regulations, such as limits on the overall leverage of an institution, are not tied explicitly to the credit risk of assets held by an institution. Operationally, risk-based regulations define capital measures (the familiar tier 1 capital, tier 2 capital, and total capital) and provide rules for calculating risk-weighted assets. Risk-based capital ratios are calculated by dividing a depository's qualifying capital by its risk-weighted assets. Generally, a depository institution is expected to operate with a total risk-based capital ratio of more than the minimum regulatory 8 percent and minimum tier 1 capital ratio of 4 percent. The current and proposed capital standards use different frameworks to calculate risk-weighted assets and different measures of regulatory capital.

Depositories' own risk models, which underpin their economic capital calculations, are used (in part) to compute Basel II risk-based capital. Specifically, a depository institution must estimate, in the 
case of residential mortgages, the probability of default (PD) for each mortgage pool and the likely size of the loss that would be incurred in default (that is, the loss given default or LGD). ${ }^{8}$ These estimates of default probability and loss severity will be components of regulatory formulas used to determine the minimum capital required to back the credit risk on a given portfolio.

The Basel II capital requirements proposed for first-lien residential mortgages were calibrated with economic capital estimates derived using the Federal Reserve Board (FRB) credit risk model. The FRB model estimates PDs, LGDs, and economic capital for various credit score-loan-to-value (LTV) pairs using (1) a target insolvency rate consistent with historical default rates in the ratings range of $\mathrm{BBB}+$ to A- and (2) expected loss estimates that are based on the PD estimates and on recession-based LGDs. $^{9}$ For convenience we collapse a hypothetical mortgage portfolio's average credit score and LTV into a scalar index of credit quality, where higher values indicate better quality (lower risk). Figure 1 (top panel) presents our economic capital estimates (as gray diamonds on the vertical axis) for 184 hypothetical mortgage portfolios of different credit quality against their credit quality index (shown on the horizontal axis). ${ }^{10}$

Estimated regulatory capital charges under Basel II for the same mortgage portfolios are shown by the black dots in the figure. ${ }^{11}$ By design, the outer boundary of the Basel II regulatory capital estimates (the solid black line) is a fairly close approximation to the economic capital estimates from the FRB credit risk model, except for riskiest mortgages, which carry a higher capital charge.

The bottom panel of figure 1 compares the proposed Basel II capital requirements with current regulatory capital requirements, including the Basel I and GSE capital requirements. ${ }^{12}$ Under Basel I, most mortgages that are fully secured by first liens on one- to four-family residential properties face a minimum "total risk-based" capital requirement equal to 4 percent of assets, regardless of their credit quality (the horizontal dashed black line). Clearly, the Basel II capital requirements (the solid black line, repeated from the top panel) are more sensitive to credit risk than the Basel I capital requirements, in that they are higher for riskier loans and lower for safer loans.

Basel I rules typically require far less capital for mortgages held in the form of mortgage backed securities (MBS) as opposed to mortgages held directly on depository balance sheets. MBS guaranteed by the GSEs carry a risk weight of 20 percent, and private-label MBS rated 'A' or better carry a risk weight of 50 percent. Thus, a pool of mortgages that would carry a capital charge of 4 percent would, if guaranteed by a GSE, carry a capital charge of 1.6 percent (shown as the dash-dot horizontal line). Of course, in this case the depository would have to pay the GSE guarantee fee. As shown by the horizontal black line, the GSE minimum capital requirement for credit risk is 45 basis points. Roughly speaking, then, a dollar's worth of mortgage consumes 4 cents of capital when held directly by a depository but only 2.05 cents of capital ( 1.6 cents from the depository and 0.45 cents from the GSE) when sold to a GSE and held as MBS. More generally, the Basel I risk weights on financial assets (such as MBS) depend on the 
asset's rating, as shown in the top panel of table 1. (In section 3 we discuss how frictions such as adverse selection affect the equilibrium volume of securitization.)

The risk weights for financial assets under Basel II depend on credit ratings, the effective number of underlying exposures, and the seniority of the position (see table 1, bottom panel). Thus, for example, for a senior position in a AAA-rated security (such as a GSE MBS), a Basel II adopter would be required to hold 0.07 times 0.08 (or 56 basis points) in capital. These financial asset risk weights are used only when the implied capital requirement is smaller than the capital requirement derived using the supervisory formula because, in the Basel II framework, the maximum regulatory capital required for a securitization exposure is set equal to the amount that would have been required had the exposure not been securitized.

Under the Basel I framework, whole mortgages held in the depository institution's portfolio are subject to the same amount of regulatory capital regardless of the credit risk of the portfolio, but equivalent MBS can be backed by less capital. Most estimates of the economic capital needed to support the credit risks of typical mortgages are well below the 4 percent regulatory capital required. ${ }^{13}$ Consequently, the mismatch between economic capital measures and regulatory capital requirements has provided a strong incentive to trade mortgages for equivalent MBS, thereby pushing mortgages off the balance sheets of the originating depository institutions and into the secondary markets. ${ }^{14}$

The Basel II capital charges shown here are designed to cover only unexpected credit losses; depositories are expected to provide capital separately to cover expected losses. In contrast, Basel I capital charges are designed to cover both expected and unexpected losses. Thus, to make the Basel I and Basel II capital charges shown in figure 1 comparable, one has to add the capital required to back expected losses to the Basel II charges. We consider this extra charge in our measure of prudent economic capital, below.

\subsection{Prudent Economic Capital}

Prudent economic capital is our approximation of what a prudent manager with an economic capital allocation system would hold given the predictability of potential credit losses over a business cycle. Our estimates of Basel II regulatory capital are probably lower than the total amount of capital that a depository would actually hold against the credit risk of mortgage pools. First, some depositories will choose a target insolvency rate that is consistent with a better rating than an A-. ${ }^{15}$ Second, investors are aware that the dependence across risk exposures may be driven by more than a single systematic risk factor. ${ }^{16}$ Third, potential errors in credit modeling will need to be covered by a capital charge partly because proprietary models will not be completely transparent to investors.

We proxy prudent capital with the sum of the FRB credit risk model estimate of economic capital and an estimate of expected loss (defined as the probability of default times the loss given default, or PD•LGD) that uses an LGD set equal to loss severity rates when credit losses are particularly high. ${ }^{17}$ In 
figure 1 (bottom panel), these capital levels are represented by light gray squares. The corresponding dashed light gray line, which is a line drawn through these estimates of prudent economic capital, generally lies everywhere above the Basel II capital requirements. Thus, our estimates of prudent capital are consistent with the view that risk managers and market participants may hold more capital than the minimum Basel II regulatory capital estimates. To the degree that credit rating agencies rely on prudent economic capital (as opposed to the regulatory minimums) as the support for a high rating on MBS, it becomes the effective market-based capital requirement for mortgages that tend to be securitized. ${ }^{18}$

By using the credit loss distribution generated by the FRB credit risk model in our estimate of prudent economic capital, we are assuming that managers of depository institutions would use their own model-based estimates of credit losses for their decision making, rather than using an estimate based on the Basel II capital formula. We include the stress-based expected loss in the estimate of prudent economic capital for at least three reasons. First, to make the Basel II capital estimates comparable to Basel I capital estimates, some measure of expected loss needs to be added to the Basel II capital estimate. (Basel II assumes that expected losses would be covered through loan loss reserves.) Second, it is reasonable that bond market investors and the rating agencies would want depositories to hold some capital to cover losses that are historically consistent with the severe losses observed during previous recessions. And third, by including the stress-based expected losses in prudent economic capital, depositories with riskier portfolios would have larger observed buffers over the proposed Basel II regulatory minimums than depositories with safer portfolios. In this manner, the prudent economic capital estimate includes a buffer over the Basel II capital requirement that is conservative and dependent on the credit quality of the mortgage portfolio.

\subsection{When Regulatory Capital and Prudent Capital Differ}

Prudent economic capital estimates have often been inconsistent with regulatory capital requirements. For example, our prudent economic capital estimates, which include an expected loss measure, are less than the Basel I regulatory requirement of 4 percent, shown by the black dashed horizontal line in the bottom panel of figure 1, for about 70 percent of the credit score - LTV pairs considered. We show below that these credit score - LTV pairs represent more than 90 percent of outstanding mortgages in the United States. But for the lowest quality mortgage pools, our estimates of prudent economic capital are greater than the Basel I regulatory requirement. In addition, the minimum GSE regulatory capital requirement for credit risk-45 basis points (figure 1, bottom panel thin solid black horizontal line) - is above our prudent economic capital estimates for the highest credit quality mortgages (that is, those with a credit quality index greater than about 0.8). ${ }^{19}$ 
Depository institutions, in practice, generally hold more than the minimum regulatory capital. This practice is puzzling, because it suggests that capital may not be more costly than other forms of nondeposit funding. If, as Modigliani and Miller (1958) suggest, debt costs rise as equity falls, it may be the case that banks are compensated for their extra capital by lower borrowing costs. The obvious violation of Modigliani-Miller equality is federal deposit insurance; insured depositors have no incentive to demand yields that reflect the credit risk associated with a depository. However, even though retail insured deposits may be a cheap source of funding, they can be costly to raise. For example, banks must build and staff a significant retail branch network to raise deposits. Indeed, the largest bank holding companies may consider core deposits too expensive to fund most of their assets. As table 2 shows, the ten largest bank holding companies fund only 30 percent of their assets with core deposits. This ratio rises as bank holding companies become smaller, but even then only about 50 percent of assets at bank holding companies not among the largest 50 companies are funded with core deposits.

In addition, depositories may desire to hold capital above either prudent economic or regulatory capital (that is, buffer capital) because of rigidities and adjustment costs. In practice, depositories may not be able to adjust capital or portfolio risk instantaneously because of market illiquidity, transactions costs, and other factors. Moreover, under asymmetric information, raising capital could be interpreted as a negative signal with regard to a depository's value (Myers and Majluf, 1984)), so managers may be unable or reluctant to react immediately to negative capital shocks. Finally, raising capital may be more costly than resorting to other forms of funding.

Consequently, lowering a depository institution's regulatory capital requirement also may lower its desired buffer capital. But as the capital requirement declines, buffer capital may not decrease at the same rate, depending on the asset volatility associated with a depository's portfolio.

Because it is difficult to predict how a change in capital requirements might affect buffer capital holdings, we estimate a range for the potential decline in mortgage lending costs that could result from lower regulatory capital requirements that allow depositories to replace some of their equity capital holdings with debt financing. (If depositories do shed equity capital because of lower regulatory capital requirements, they must fund existing and increased asset holdings from other sources, i.e., debt). For the low end of the range for cost savings, we assume an equity premium equal to 2.7 percent, which implies that a decline of 1 percentage point in required equity capital would result in a funding cost saving of 2.7 basis points. ${ }^{20}$ For the high end of the range for cost savings, the before-tax return on equity is assumed to equal 15 percent, ${ }^{21}$ and the cost of debt is assumed to equal 6.25 percent, ${ }^{22}$ the latter of which implies that a decline of 1 percentage point in equity capital would result in a funding cost saving of 8.8 basis points $(0.01 \cdot[0.15-0.0625])$. 
Whatever the actual cost savings from any reduction in minimum regulatory capital, only if the adopter offers a lower mortgage rate in response will Basel II affect the adopter's market share of mortgage originations. Such changes, if they occur, may come at the expense of the GSEs or at the expense of nonadopters. As we argue below, our analysis suggests that, regardless of the cost savings, any changes will likely be rather small and limited to a few corners of the mortgage market.

\section{Mortgage Pricing and Depository Behavior}

In this section, we develop a theoretical model of equilibrium pricing in mortgage markets. Our model captures the role of shifting capital regulations, securitization, and adverse selection. While our model does assume that the mortgage market can be divided into broad segments characterized by uniform pricing, as we discuss below, our main results are unchanged if we allow perfect risk-based pricing.

Based on our model, we argue that most depository institutions will not actually realize a change in their capital costs for most mortgages even if they do adopt Basel II and that equilibrium retail mortgage rates faced by most borrowers will not be affected by Basel II.

Intuitively, capital regulations will have little effect because a necessary condition for capital regulations to affect equilibrium outcomes is that retail mortgage rates vary with the credit risk (and thus the capital charge). However, the mortgage market currently consists of large market segments in which it appears that mortgage rates do not vary with respect to credit risk differences within these segments.

Moreover, regulatory capital arbitrage has already significantly reduced the role of capital regulations on retail pricing. That is, through securitization and other financial innovations, depositories have lowered their regulatory capital requirements without materially reducing their overall credit risk

exposures. $^{23}$ Two mechanisms have facilitated this arbitrage: (1) the GSEs and other securitizers currently bear the credit risk on most U.S. mortgages, and their required capital ratios for bearing that risk are generally lower than those ratios that apply to bank and thrift organizations; and (2) banks and thrifts can currently combine some low-risk and high-risk mortgages to meet Basel I-type capital standards and leverage requirements. ${ }^{24}$ Thus, the financial system as a whole already holds only a small amount of capital against the credit risk posed by conforming mortgages.

\subsection{Uniform Pricing and Adverse Selection in Secondary Markets}

To understand who bears mortgage credit risks, one must consider the roles of originators and securitizers in funding residential mortgages. Both GSEs and private securitizers typically purchase mortgages that are originated by others. Because they do not originate mortgages, securitizers must guard against buying a relatively high proportion of higher-risk mortgages from originators. In general, the 
advantage that originators as "first movers" have in their transactions combined with the prevalence of uniform pricing in the mortgage markets implies that mortgage securitizers will set tougher underwriting standards than will mortgage originators, who can both underwrite and hold mortgage credit risk. ${ }^{25}$

Our analysis assumes that mortgage markets are characterized by uniform pricing and that the mortgage rate equates the marginal cost of bearing credit risk for the marginal borrower in each market segment with that borrower's willingness to pay for the mortgage. Our results hold in somewhat modified form even if mortgages are perfectly risk-priced. Hancock, Lehnert, Passmore, and Sherlund (2005) adduce several reasons to expect uniform pricing within mortgage market segments, including a study of mortgage pricing using the 2001 Survey of Consumer Finances.

Other researchers have found similar results. Duca and Rosenthal (1994) argue that mortgage originators are frequently subject to fair lending standards, which discourage loan-specific pricing that appears to price discriminate between borrowers; they conclude that "conventional lenders do not vary fixed-rate mortgage rates on the basis of observable differences in credit risk.” Gates, Perry, and Zorn (2002) argue that the great uncertainty in identifying loans that will ultimately default has led mortgage lenders to price risk on average within broad segments. Gates, Perry and Zorn also argue that uniform prices promote affordable housing goals and demonstrate that use of Freddie Mac's Loan Prospector automated underwriting system, plus the business practice of setting fixed guarantee fees for all loans delivered under a contract, results in higher approval rates for borrowers, especially underserved applicants.

Uniform pricing may lead a mortgage originator who has the option of holding a mortgage in its own portfolio to withhold safer mortgages from a mortgage pool. By "cherry picking” the safer mortgages, the originator avoids paying a mortgage securitizer or insurer the guarantee fee, which is often an average fee for a pool of mortgages. In response, mortgage securitizers generally set tougher underwriting standards than mortgage originators do. Heuson, Passmore, and Sparks (2001) show that tougher standards can arise even when all market participants have full information about the credit risks associated with the mortgages. In addition, Passmore and Sparks (1996) show that adverse selection, when the originator has better information than the mortgage guarantor has, can also lead to tighter underwriting standards. Cutts, Van Order, and Zorn (2001) note that the practice of uniform pricing and the resulting concern over adverse selection causes mortgage guarantors, such as Freddie Mac and Fannie Mae, to set a maximum level of risk that they are willing to accept and to enforce it through underwriting standards. Steinbach (1998) argues that mortgage pricing maintains an element of cross-subsidization (and thus uniform pricing) because collateral risk is more dominant than credit risk and collateral risk cannot be forecast with precision. 
Depository institutions, however, may be unable to exploit their first-mover advantage or their knowledge of primary mortgage markets to the same extent as other originators because their capital requirements for mortgages, under Basel I, exceed the appropriate economic capital for the credit risk associated with some safe mortgages. As we describe below, depository institutions can effectively remove this constraint for their safest mortgages by blending them with higher risk mortgages in their mortgage portfolios. $^{26}$

\subsection{Supply within a Given Mortgage Market Segment}

A graphical representation of the industry supply curve for a given segment of the mortgage market appears in the top panel of figure $2 .^{27}$ On the horizontal axis is the probability $q$, ranging from 0 to 1, that a mortgage will not default. Thus although we assume that market participants treat mortgages in this segment as homogenous enough to support uniform pricing (one price for all mortgages in the segment), we still assume that there is significant variation in the mortgages' credit risk within the segment. Mortgages with higher probabilities of not defaulting (those where $q$ is closer to 1 ) have the lowest credit risk. The marginal cost of bearing mortgage credit risk declines as $q$ increases so that the lowest rate a lender is willing to accept falls as $q$ rises. ${ }^{28}$

The black solid and dashed curve is the depository institution's marginal cost for bearing credit risk within the given mortgage market segment that incorporates regulatory capital requirements that are not sensitive to changes in credit risk, such as the Basel I standards. ${ }^{29}$ This line flattens as credit risk falls ( $q$ rises) because the minimum "total risk-based capital” requirement and the leverage requirement are constant. As we argue below, this marginal cost curve is not the one that effectively constrains the decisions made by depositories subject to Basel I-type capital standards. Analogously, the dark gray solid and dashed curve is the securitizer's marginal cost for bearing credit risk that again incorporates a capital requirement that is not sensitive to changing credit risk (e.g., a capital charge of 45 basis points for the credit risk on all conforming mortgages).

The light gray solid and dashed curve represents the marginal capital costs associated with holding prudent economic capital to back mortgages of different credit quality. This line is steeper than the black line because prudent economic capital, unlike Basel I capital standards and leverage requirements, varies with respect to mortgage credit quality. Because the black and light gray lines are of different slopes and curvature, the distance between these lines is indicative of potential distortions associated with leverage ratios and the Basel I capital standards.

The securitizer is assumed to hold the prudent economic capital needed to back the mortgage (represented by the light gray line) when it is higher than its corresponding minimum capital requirement (represented by the dark gray line).$^{30}$ The securitizer's marginal cost curve, composed of the solid light 
gray and dark gray line segments (which fall between $q_{1}$ and $q_{3}$ ), is lower than the black line because securitizers, who may be subject to lower capital requirements for mortgage credit risk and may have greater liquidity for their publicly traded MBS, sometimes have greater geographic diversification in their mortgage pools than banks and thrifts have in their mortgage pools. In particular, for market segments in which the GSEs purchase mortgages, the marginal cost curve for these securitizers may be lower because they can issue securities in larger amounts and because investors perceive that they are implicitly backed by the government. ${ }^{31}$

Because of adverse selection, the securitizer wants to purchase mortgages only between $q_{1}$ and 1 . Because of cherry picking, the originators (including depositories) want to sell mortgages only between 0 and $q_{3}{ }^{32}$ The level of $q_{3}$ is determined by the originator's comparison of the marginal profit derived from holding the loan to the price offered by the securitizer for selling the mortgage.

A depository's decision to sell to a securitizer must take account of regulatory capital requirements, which would negate much of the additional profitability from holding a very low risk mortgage unless the depository can blend it in a portfolio with higher-risk mortgages. When blending assets, the depository combines the lowest risk loans with higher risk loans to create a portfolio that is consistent with the 4 percent regulatory capital requirement; doing so effectively equates the prudent economic capital and the required regulatory capital on the blended portfolio. ${ }^{33}$ In essence, from $q_{3}$ to 1 , the depository is bearing the cost of the prudent economic capital (the light gray line) for carrying lowrisk mortgages because of the mortgages' value in being blended with high-risk mortgages (those in the 0 to $q_{1}$ range) that have prudent economic capital above the regulatory 4 percent requirement.

The effective marginal costs for mortgage credit risk in a given market segment are represented by the solid segments of the black, dark gray, and light gray curves in figure 2. Because of regulatory capital arbitrage (through blending and securitization), the marginal costs are determined by prudent economic capital for most mortgages, even under Basel I capital standards.

The two dashed portions of the prudent economic capital line in the top panel - the light gray line - are the regions of credit risk in which regulatory capital constraints influence mortgage funding and create deadweight losses (denoted by the two cross-hatched regions). In these cases, regulatory capital constraints may bind and thus might result in artificially high prices for bearing the credit risk associated with these (low and high risk) borrowers.

In the cross-hatched area to the left, which is bounded at the top by the solid grey line, Basel I capital regulations influence mortgage rates because the depositories cannot sell their originated mortgages to any securitizer with a lower capital requirement. In other words, the depository institution cannot communicate the quality of these mortgages to the secondary market (and thus cannot sell the mortgages into the market nor securitize them). 
In the cross-hatched area to the right, which is also bounded at the top by the solid gray line, capital regulations on securitizers influence mortgage rates because no other competitor (that is, depository) has a lower prudent capital requirement. (Securitizers, unlike originators, generally cannot blend mortgages because they lack the information to adequately judge the risks associated with the individual mortgages within a market segment. However, to the extent that securitizers can develop specific risk information that is not easily duplicated or is not revealed to originators, some blending may be possible.)

Basel II increases the risk sensitivity of capital requirements, so the marginal cost curve of adopters for bearing mortgage credit risk more closely reflects prudent economic capital. In the bottom panel of figure 2, prudent economic capital is again denoted by the thin black line. To understand differences in the marginal costs of adopters versus nonadopters, one compares the effective marginal cost curve under Basel I (indicated by the dashed gray line) with the marginal cost associated with prudent economic capital (which would apply under Basel II). This comparison assumes that these marginal cost curves differ only with respect to regulatory capital requirements. Other costs are assumed to be the same and, in particular, non-capital operating costs are assumed to be identical for adopters and nonadopters under Basel II.

The marginal cost curve of adopters falls below the marginal cost curve of nonadopters in two places, indicated by the cross-hatched regions in the bottom panel. These regions represent the deadweight costs from capital regulations (like Basel I) that are not sensitive to credit risk. In the rightmost region, the marginal cost curve for adopters falls below the marginal cost curve of securitizers (which is also the marginal cost curve for nonadopters) from $q_{2}$ to 1 . Here, the adopters would choose to hold mortgages with $q$ above $q_{2}$ and would sell fewer loans to the securitizer. Thus, Basel II has the potential to place some of the safer mortgage loans back on depository institution balance sheets and reduce the role of securitization in funding mortgage loans. Also, adopters of Basel II would hold a higher-quality segment of the low-quality credits (with probabilities of not defaulting on the loan ranging from $q_{0}$ to $q_{1}$ ) in a mortgage market segment because they could carry only the prudent economic capital needed to back these loans rather than the higher requirement of Basel $\mathrm{I}^{34}$

Finally, depository institutions would likely continue to retain the safest mortgages, those with probabilities of not defaulting ranging from $q_{3}$ to 1 . Adopters would retain these mortgages because of the low prudent economic capital required to back the associated credit risk. Nonadopters would continue to blend these highest-quality loans with their riskier mortgages (and possibly other credit risk intensive assets) to meet their Basel I capital requirements. 


\subsection{Potential Equilibrium Mortgage Rates}

The equilibrium mortgage rate for a mortgage market segment is determined where the demand curve for that segment crosses the industry supply curve. ${ }^{35}$ The demand curves in this model (figure 3 , curves $D_{1}$ through $D_{4}$ ) rank borrowers by the maximum interest rate they are willing to pay for a mortgage. The model assumes that borrowers with a high probability of paying back their mortgage are willing to pay higher mortgage rates, all other things being equal, because mortgage default is costly for borrowers. Put another way, when high mortgage rates prevail, only borrowers with low odds of default apply for mortgages. ${ }^{36}$ When the demand schedule is characterized by curve $D_{1}$, all borrowers willing to pay more than the equilibrium mortgage rate, $R_{1}$, both demand and receive a mortgage (these are borrowers with a probability of not defaulting on their mortgage greater than or equal to $\bar{q}$ ).

As discussed earlier, only one mortgage rate prevails in each mortgage market segment. As shown in figure 3, Basel II has the potential to lower mortgage rates charged to borrowers only if a mortgage market segment demand curve crosses the industry supply curve in the areas where Basel II would effectively lower the cost of mortgage funding through reductions in capital needed for credit risks (as shown by the demand curve $D_{2}$, which crosses the supply curve between $q_{0}$ and $q_{1}$, and $D_{4}$, which crosses the supply curve between $q_{2}$ and $q_{3}$ - i.e., the rates $R_{2}$ and $R_{4}$ are lower than they would be under Basel I). Depending on the shapes of the demand and supply curves, adopters might have lower costs and, therefore, a pricing advantage over nonadopters for a segment of the mortgage market. In contrast, $R_{1}$ and $R_{3}$ are unaffected by the implementation of Basel II capital standards because regulatory capital requirements are not binding for the marginal borrower under the current capital standards and therefore adopters would not realize a pricing advantage under Basel II. Only if mortgage demand falls in the particular regions that are delineated with cross-hatching will mortgage rates fall; otherwise, the marginal cost of bearing the credit risk of the marginal borrower in the particular mortgage market segment is unaffected, and the mortgage rate is unchanged. As discussed below, it seems unlikely that mortgage rates for most U.S. mortgage market segments are determined by demand falling in these cross-hatched regions.

\section{The Effect of Capital Requirements on U.S. Mortgage Markets}

So far, we have described capital regulations and discussed their theoretical implications for equilibrium mortgage pricing. In this section, we provide a detailed taxonomy of the U.S. mortgage market and the broad credit risk segments that we analyze. We are unaware of any other study that comprehensively estimates the size of various mortgage market segments and determines the effect of bank capital regulations on each segment. 
Because our description is based on several different data sources, we analyze a snapshot of the mortgage market as of the third quarter 2003. At that time, mortgage debt on single-family homes in the United States totaled about $\$ 6.6$ trillion, of which roughly 94 percent was conventional - that is, not insured by either FHA or VA. ${ }^{37}$ Some of these mortgages were second liens, meaning that they are most likely home improvement or home equity loans. Excluding these loans, the first-lien, conventional mortgage market was about $\$ 5.3$ trillion.

Mortgages are often said to be either "prime” or "subprime," making this division an obvious starting point for our discussion of market segments. However, there is no generally-accepted definition of prime and subprime mortgages. Rather, prime and subprime designations are usually made by a mortgage institution (often an originator or a servicer) with an intent to sell the mortgage into the secondary market, and these designations often are based on a combination of the borrower's creditworthiness and the collateral value of the home being financed. In particular, a borrower's creditworthiness is frequently measured by his or her credit score, and the degree of collateralization is measured by the LTV ratio of the mortgage. However, other measures of creditworthiness, such as a household's debt-to-income ratio, might also be used. "Prime" borrowers are seen as less likely than "subprime" borrowers to default, with the default risks associated with "near-prime” borrowers or "alt-A subprime” borrowers being somewhere between prime and subprime borrowers. ${ }^{39}$

Given the lack of generally accepted definitions for "prime" and "subprime," we propose a straightforward split of the mortgage market that is consistent with industry practice and is tractable for understanding how the Basel II capital requirements might influence mortgage pricing. ${ }^{40}$ Specifically, our mortgage market segments are based solely on credit scores and LTV ratios. Therefore, many of the nuances of the marketplace, where originators and securitizers have more detail about each household's financial history and debt obligations, are not taken into account.

As in Hancock, Lehnert, Passmore, and Sherlund (2005), we divide the first-lien, conventional mortgage market into three broad credit risk segments: (1) prime mortgages, (2) near-prime mortgages, and (3) subprime mortgages. We define "prime" mortgages as those extended to borrowers with a credit score of 660 or more and an LTV ratio of 80 percent or less. "Near-prime” mortgages are defined as those extended to borrowers with a credit score greater than or equal to 580 but less than 660 and an LTV ratio of 90 percent or less, or to borrowers with an LTV ratio greater than 80 percent and less than or equal to 90 percent and a credit score above $660 .^{41}$ "Subprime" mortgages are defined as those extended to borrowers with a credit score of 580 or less or an LTV ratio greater than 90 percent. $^{42,43}$ These definitions are summarized in table 3.

Individual financial institutions almost certainly classify mortgages into more than these three broad categories. However, even this coarse taxonomy required estimating the number of mortgages in each of nine separate credit score - LTV buckets. Individual financial institutions may have complete 
data on the mortgages in their portfolio. However, available public data on all mortgages in the U.S. cannot reasonably support a finer taxonomy.

We estimate that there were roughly 40.7 million single-family, first-lien, conventional mortgages outstanding in the United States at the end of the third quarter of 2003 (figure 4, top box). ${ }^{44}$ Using a national sample of credit scores provided by one of the three national credit-reporting agencies, LTV ratios from LoanPerformance Corp., and imputed credit scores derived from the Survey of Consumer Finances, ${ }^{45}$ we estimate the amount of mortgages held in the credit score - LTV ranges for prime, nearprime, and subprime mortgages. ${ }^{46}$ Our analysis suggests that of outstanding mortgages 29.7 million are prime (73 percent), 5.9 million are near-prime (15 percent), and 4.9 million are subprime (12 percent). Within these categories we also estimated the number of mortgages that carried fixed interest rates, and the number that were securitized; we discuss these features below.

We estimate prudent economic capital levels for the credit risks of mortgages within each of the mortgage market segments (prime, near-prime, and subprime) and compare these levels to (1) Basel II regulatory capital requirements, (2) Basel I capital requirements for holding mortgage loans on the balance sheet, and (3) GSE capital requirements for bearing credit risk. We also consider capital levels established through private securitizations, which are assumed to be at least equal to prudent economic capital. These comparisons allow us to infer the proportions of each mortgage market segment where competition would likely be affected by the bifurcated approach for implementation of the Basel II capital standards. $^{47}$

\subsection{Estimated Economic and Regulatory Capital by Market Segment}

We computed prudent economic capital and Basel II minimum regulatory capital for many different combinations of credit scores and LTV ratios. We then assigned each combination to one of the three market segments (prime, near-prime and subprime) we defined in table 3 . In figure 5, we compare the capital required to back these loans under Basel I and Basel II, as well as under the GSE regulatory regime; nonadopters would continue to face the Basel I requirements.

In the high-credit score, low-LTV region (the cross-hatched region), the Basel II minimum capital requirement is lower than the minimum capital requirements for both nonadopters (4.0 percent for holding the whole mortgage) and the GSEs (45 basis points). ${ }^{48}$ In contrast, in the low-credit score, highLTV region (the gray shaded region), the Basel II minimum capital requirement is higher than the capital requirements for either the nonadopters or the GSEs. ${ }^{49}$ In the intermediate (unshaded) region, Basel II adopters have lower minimum capital requirements than nonadopters but a higher minimum capital requirement than the GSEs. (We assume, however, that in this case the GSEs would hold the prudent amount of economic capital, not just their minimum capital requirement.) In addition, in the intermediate 
and shaded regions, private securitization would establish a minimum benchmark of prudent economic capital.

Figure 5 also shows the median estimated Basel II capital for the intersections of the mortgage market segments and the capital requirement regions. For example, the median capital charge under Basel II for a prime mortgage (in the inner left box) given that the capital charge is below the GSE minimum capital requirement (in the cross-hatched region) is 20 basis points. As another example, the median Basel II minimum regulatory capital estimate for a subprime loan (in the outer right box), given that it has an estimate exceeding the Basel I requirement of 4 percent (in the shaded region), is 725 basis points.

\subsection{Basel II Capital Standards and Securitization Incentives}

During the late 1980s and early 1990s, depositories developed relationships with the GSEs to securitize mortgages; securitization allowed the depositories to equate regulatory and prudent economic capital requirements. These conduits are now well embedded in U.S. mortgage markets. By using GSE securitization, the depositories get a capital savings under the current regime (by dropping from a riskweight of 50 percent to a risk-weight of 20 percent) but pay the GSEs’ guarantee fee. Roughly speaking, for $\$ 100$ of mortgages, the marginal capital requirement drops from $\$ 4.00$ to $\$ 1.60$ by using a GSE securitization to hold mortgages under Basel I. We estimated that equity capital is between roughly 9.2 and 2.5 percentage points more costly than debt financing. Thus, a 240 basis point decrease in required capital translates into a likely saving of between 6 and 22 basis points. With the average GSE guarantee fee around 21 basis points, the net savings to a depository appears to be minimal.

A second, and perhaps even more important, reason for securitization is the liquidity motive. Depositories wish to increase their available funds by selling the less-risky portions of their mortgage portfolios to other institutions (such as life insurance companies and pension funds) with a desire to hold low risk assets. Large banks in particular engage in so-called private label securitizations (i.e. non-GSE securitization). The banks typically originate a large volume of mortgages and then package their cash flows so that they back a variety of securities with payment characteristics and credit risk. Depositories usually continue to hold on their balance sheets a first-loss position in the securitization designed to absorb most of the credit risk in the pool. By taking the first-loss position, depositories pledge enough credit support to the more senior tranches of the securitization, so that the securities achieve a desired investment-grade rating. Under current U.S. capital regulations, these first loss positions have to be backed dollar-for-dollar with capital.

Under Basel II, depositories will still be able to create a first-loss position to guarantee the credit risk and will have the opportunity to sell the rest. Capital will continue to be held dollar-for-dollar behind 
the first-loss position. Thus, the desire for liquidity will provide a motive for depositories to continue to securitize those mortgages that have tended to be securitized under Basel I.

The one exception to this conclusion is GSE securitization. GSE securities are backed not by depository capital holdings but by GSE capital holdings. The GSEs have a minimum capital requirement against credit risk of 45 basis points, and they often price their guarantee fees to reflect the average risk of a mortgage pool. ${ }^{50}$ As we spell out below, adopters may be more prone not to sell conforming mortgages to the GSEs unless GSE guarantee fees are lowered.

In contrast to GSE securitization, the pricing of credit risk associated with private label MBS is unaffected by the implementation of Basel II because these securities are already backed by prudent economic capital. Therefore, Basel II does not alter the cost of guaranteeing the credit risk of a particular mortgage pool. Ultimately some entity already holds the economic capital needed to cover the credit risk of the underlying mortgages, and market participants will continue to seek the appropriate economic capital backing for mortgage pools even after the implementation of Basel II.

Combining information on the distribution of mortgages by type (figure 4) with information on the potential capital savings to adopters on mortgages of different quality (figure 5) gives us a sense of the industrywide total capital savings available to adopters versus non-adopters, as well as the number of mortgages likely to be contested between the adopters and the GSEs. We consider each mortgage segment in turn.

\subsection{The Prime Mortgage Market and the Potential Advantage of Basel II}

In the prime mortgage market, the mortgage rate is determined by a securitized mortgage that is already backed by prudent economic capital. In other words, the mortgage rate is determined by a demand curve that falls in the region between $q_{1}$ and $q_{2}$ (that is, $\mathrm{D}_{3}$ ) in figure 3 . In addition, as suggested by figure 3, there can be substantial changes in marginal costs (e.g., the distance between the blackdashed and solid light gray lines between $q_{2}$ and $q_{3}$ ) without influencing the equilibrium mortgage rate, $R_{3}$. These changes, however, may result in changes in revenues of market participants and also may influence securitization activities.

\section{The Market for Conforming Fixed-rate Prime Mortgages}

Prime mortgages are by far the largest U.S. mortgage market segment (figure 4). The dominance of GSEs in this mortgage market segment suggests that it is their capital backing that underlies the market price for the credit risk of prime conforming mortgages. ${ }^{51}$ These very low risk mortgages flow to the GSEs because such entities generally have lower capital requirements with regard to credit risk than any other mortgage guarantor, unless the originator, as discussed earlier, decides to retain the best mortgages. 
The median total capital requirement under Basel II for a prime mortgage in the dark gray region of figure 5 is around 20 basis points by our estimates - for all prime mortgages the median total capital requirement would be around 30 basis points (not shown). In figure 6, we present estimates of the shares of each market segment that fall under different capital regimes. For example, for the prime mortgage market, we estimate that adopters will have credit risk capital costs lower than those of either nonadopters or GSEs for about 88 percent of prime mortgages (the cross-hatched region of the prime market).

Following the adoption of Basel II, pricing of credit risk in the prime market probably will continue to be heavily influenced by GSE underwriting standards, with its 45 basis points of minimum regulatory capital, and not by the changes brought about by Basel II. The more marginal borrowers in the prime mortgage market tend to require more than 45 basis points of prudent economic capital (as shown by the white area in the prime mortgage box in figure 5 , the median prudent economic capital estimate is 65 basis points). As a result, there will likely be little change in prevailing mortgage rates for prime fixed-rate mortgages because of Basel II (since, as illustrated by $\mathrm{D}_{3}$ in figure 3, mortgage demand does not cross the mortgage supply curve in a region where adopter capital constraints are currently binding).

\section{New Competition among Adopters and GSES}

The adopters of Basel II could also insure against the credit risk of prime mortgages by purchasing a credit guarantee from the GSEs. The average GSE mortgage guarantee fee is around 21 basis points, but most adopters would also likely be large originators of mortgages and thus probably pay less than this average fee - more like 15 to 18 basis points.

An adopter's costs associated with the capital to back a credit guarantee for a conforming prime mortgage would, we estimate, be about 2 basis points, seemingly much less than a guarantee fee of 15 to 18 basis points. ${ }^{52}$ However, the total cost to an adopter of keeping a mortgage is more than just the capital carrying cost. Indeed, the other costs associated with providing a credit guarantee, such as dealing with foreclosures and managing the cash flows coming from mortgage payments, often exceed the cost of the carrying capital. To make an appropriate comparison of an adopter's choice of buying a guarantee fee versus holding the credit risk of a mortgage directly, we must extract these other costs from the GSE guarantee fee.

For example, from its 2003 financial data reported by line of business, Fannie Mae's net income on its credit guarantee business, calculated as a share of the stock of outstanding MBS, appears to have been about 13.4 basis points. Fannie Mae’s credit losses on mortgages were minimal - about 0.6 basis points. For illustrative purposes, we will roughly approximate Fannie Mae's income net of ongoing credit risks and other costs as 12 basis points. ${ }^{53}$ Assuming that the GSEs' net costs of capital are the same as the adopters' costs, their carrying costs of capital range from 1 to 4 basis points. ${ }^{54,55}$ Thus, the remaining 8 to 
11 basis points in net income represents an extra return on GSE capital, of which part may reflect the liquidity benefits of the GSE MBS market, part may be an implicit subsidy derived from the GSEs' implicit government backing, and part may reflect the GSEs' market power in pricing MBS guarantees.

An adopter might view this remaining 8 or 11 basis points of GSE net income as the contestable portion of the GSE mortgage guarantee fee. With such a large difference in returns on equity, the GSEs would probably be under some pressure to reduce their guarantee fee. However, the adopter would need to consider the other possible reasons for the apparently large difference between the GSE return to capital and the competitive return to capital, and thus might continue selling its mortgages to the GSE. Overall, it is difficult to know if this apparent difference between the adopter's costs and the GSE guarantee fees would result in a substantial number of mortgages not being sold to the GSEs. In terms of basis points, the savings from Basel II on the credit guarantee for prime mortgages may not seem large. But the prime mortgage market is extremely large and a few basis points can represent a substantial amount of income.

Indeed, one might even argue that the adopters would enter the mortgage securitization business and compete directly with the GSEs. But, as noted earlier, most adopters are large originators and sellers of mortgages to the GSEs. Given the high returns on capital currently earned by the GSEs, the guarantee fees charged to adopters seem likely to fall once Basel II is adopted. Thus, the GSEs may face some loss of income with the adoption of Basel II. However, the appeal of the GSE credit guarantee to depository institutions is not exclusively its lower capital costs. Instead, it may be the liquidity associated with implicitly government-backed securities, a possibility suggesting that the adoption of Basel II may not substantially alter current arrangements.

Any decline in guarantee fees for adopters seems unlikely to influence the guarantee costs for nonadopters. The GSEs already negotiate separate guarantee fees for large originators that sell their mortgages to the GSEs, and thus the guarantee fees charged to nonadopters are not linked to the fees charged to adopters. In addition, the mortgages held by nonadopters and not sold to the GSEs are probably carried with the appropriate amount of prudent economic capital through the use of blended portfolios. Given the GSEs’ significant regulatory capital advantage relative to depositories for bearing the credit risk of prime mortgages under Basel I, nonadopters appear unlikely to sell mortgages not currently sold to the GSEs to anyone else with a similar capital standard.

\section{The Market for Prime Adjustable Rate Mortgages (ARMs)}

About 11 percent of prime mortgages have adjustable rates. The conventional wisdom is that GSEs tend to purchase few ARMs because depositories are loath to sell them. ARMs, in this view, are a better match for the interest rate risk of depository. However, this view does not explain why depositories tend 
to hold the credit risk of many of their ARMs. ${ }^{56}$ Banks and thrifts could still sell the credit risk to GSEs. The resulting ARM-backed MBS could be kept on portfolio, and this security would match depository liabilities as well as the whole-loan ARMs.

Our earlier capital cost calculations for GSE securitizations suggest that banks and thrifts likely do not securitize many of their mortgages because such small savings may not warrant the effort, and this behavior seems unlikely to change with the implementation of Basel II. ARMs, in particular, are unlikely to be securitized (1) because the administrative costs associated with securitizing these mortgages may be large because of a lack of product standardization or (2) because the depository never intends to sell the mortgage (and thus never needs the liquidity provided by the GSE guarantee). In contrast, fixed-rate mortgages are largely standardized and depositories might benefit from the liquidity provided by a GSE guarantee as part of their interest rate risk management strategy. Thus, the bulk of the prime mortgage credit guarantees that adopters might contest after Basel II is implemented are likely fixed-rate mortgages sold to the GSEs under the current capital regime.

\section{Effects of Basel II in the Prime Market Segment}

Overall, the main effect of Basel II in the prime market segment appears likely to be possible transfers of wealth from GSEs to adopters. In contrast, the mortgage rate would likely be unaffected because the capital required to back mortgages extended to the marginal borrower in the prime market would probably be unchanged.

With respect to the wealth transfer from GSEs, although the number of basis points to be split between the GSEs and the adopters is small, the number of mortgages that might be affected is large. We provide estimates of the number of mortgages affected by Basel II in figure 4. These estimates are based on the existing stock of mortgages and therefore do not represent the numbers that would be affected in any given year. The stock of mortgages, however, gives us an indication of whether a potential change may affect many or only a few households and what proportion of the mortgage market may be affected over a long period.

Of the 18.4 million fixed-rate, securitized prime mortgages we estimate that 16.2 million were sold to the GSEs and thus would have guarantee fees that the Basel II capital standards could affect (figure 4, shaded box on left). Although this is a high proportion of the prime mortgage market, when all factors are considered, the incentives for the GSE guarantee function to be displaced by adopters are small, and of course, any change brought about by Basel II would take years to influence all mortgages. Thus, these numbers based on our estimates of current mortgages outstanding should be taken as only indicative of the maximum long-run competitive effects, and the speed of adjustment in mortgage terms 
and prices would depend on many factors, including those that influence mortgage turnovers, such as interest rates and house prices.

The decrease in required capital under Basel II compared to Basel I is largest for the safest mortgages_conforming fixed-rate prime loans-which are most commonly sold to GSEs. Likely adopters (proxied by the ten largest bank holding companies ranked by asset size, the ten largest nonmandatory adopters, and the largest and most active mortgage-oriented nonmandatory adopters) sold about 58 percent of the mortgages that were bought by the GSEs. Thus, we estimate that up to 9.9 million mortgages of the existing prime mortgages securitized might have been under greater competitive pressure and therefore may have had lower guarantee fees if Basel II had been in effect in earlier years. ${ }^{57}$ However, these lower guarantee fees would not, we believe, have affected mortgage rates very much, if at all, because of the prevalence of uniform pricing methods.

\section{Non-Securitized Fixed-Rate Mortgages}

We estimate that roughly 6 million outstanding prime fixed-rate mortgages are not securitized. Our conceptual framework suggests that these mortgages are very low risk mortgages that depository institutions keep in their portfolios. At first glance, the regulatory capital charges associated with such mortgages seem to be substantially above what the market would require. However the actual capital held on such mortgages is probably close to prudent economic capital as depositories blend loans of different credit quality in their overall asset portfolio. (And such blending, of course, may not diminish even after the implementation of Basel II because of the tier 1 leverage requirement imposed by FDICIA). Because actual capital currently backing these mortgages is close to the prudent capital, competition in this market subsegment probably will be unaffected by Basel II implementation.

In addition, the capital carrying costs of discrepancies from prudent economic capital may be outweighed by other considerations. As shown in figure 5, adopters' marginal capital requirement might fall from 4 percent to as low as 20 basis points, but the actual capital savings from these discrepancies would, at most, range from 10 to 33 basis points, which could easily be offset by other factors. For example, many of these mortgages appear to be "low documentation” mortgages, which might be offered to depository institution customers with established relationships. In addition, some of these mortgages might be extended to low-risk borrowers to finance unusual property types (e.g., second homes and coops). Regardless, given the low credit risk of these prime borrowers and the seemingly high regulatory capital requirement under Basel I, it appears unlikely that capital costs played a large part in the depository institution's decision to keep many of these loans in their portfolio. And thus we do not expect Basel II implementation to greatly influence mortgage pricing in this mortgage market segment (as shown 
in figure 4, leftmost black outlined box, we estimate that at most only 3 million mortgages might by affected).

\section{The Prime Jumbo Market}

The mortgage rate in the prime jumbo market, like that in the prime conforming market, is most likely determined by a securitized mortgage that is already backed by prudent economic capital. Although GSEs cannot purchase or securitize jumbo mortgages, about one-third of these mortgages are securitized by purely private securitizers. Because of the substantial securitization activity and the small amounts of prudent economic capital associated with such mortgages, the mortgage rate in the prime jumbo market appears to be determined by a demand curve that falls in the region between $q_{1}$ and $q_{2}$ (for example, $\mathrm{D}_{3}$ ) in figure 3. In this market, Basel II would induce no wealth transfer between adopters and securitizers because securitization methods effectively equate regulatory and prudent economic capital.

The fact that nonsecuritized mortgages today might have been securitized but were not suggests that the difference between prudent economic capital (held by the securitizers) and Basel I-type capital requirements was insufficient to entice mortgage originators to sell these mortgages. Indeed, many of the main holders of these jumbo mortgages are the same bank and thrift holding companies that are heavily involved in securitizing nonconforming mortgages. One reason that capital requirements seem unlikely to change the status of prime jumbo mortgages is that some of these mortgages are ARMs (see figure 4). The capital costs of the fixed-rate component can be offset by other factors (see discussion on prime ARM). We estimate that at most only half a million prime jumbo mortgages might be affected by Basel II implementation (second black outlined box from the left, figure 4). Moreover, given the prevalence of uniform pricing in the prime mortgage market, this small change in mortgage carrying costs seems unlikely to yield any meaningful change in mortgage rates. 


\subsection{Near-Prime Mortgages and Basel II Implementation}

As shown in figure 5, Basel II capital requirements on near-prime mortgages vary widely. This range mirrors the underlying wide range of risks, suggesting that many institutions, with their varying regulatory and prudent capital standards, might play a role in this market. It also suggests that the mortgage extended to the marginal borrower has a rate consistent with the amount of prudent economic capital needed to back the mortgage. In other words, the mortgage rate in the near-prime market segment seems to be determined by a demand curve that falls in the region between 0 and $q_{0}\left(D_{1}\right)$ in figure 3 . If uniform pricing prevails in the near-prime market, the implementation of Basel II capital standards would not affect mortgage rates, and the benefit would be captured by adopters in higher profits. In figure 3 , adopters capture the cross-hatched areas that represent the deadweight losses that occur under current regulations, because, as suggested by our theory, the mortgage rate would be $R_{1}$ as determined by $D_{1}$. Indeed, some mortgages in this market seem to warrant substantial amounts of economic capital, as shown by the shaded region in figure 5 , so that the more risk sensitive Basel II capital requirements might well exceed the current capital requirements by significant amounts.

As shown in figure 6, an estimated 9 percent of the outstanding mortgages in the near-prime market segment have prudent economic capital greater than 4 percent. Since the prudent economic capital required is likely greater than the depository regulatory minimum for the marginal borrower in the near-prime market segment, the mortgage rate (e.g., $R_{1}$ ) would likely be unaffected by the implementation of Basel II capital standards. Thus, calculations of the competitive effect of Basel II on the market shares of adopters and nonadopters must operate through another mechanism rather than through changes in the mortgage rate.

One mechanism that might lead adopters to increase their mortgage market share is through additional revenues that they might accrue because of their lower capital costs (as shown by the crosshatched region between $q_{0}$ and $q_{1}$, which represent the deadweight losses associated with the current capital regulation regime, in figure 3). By our calculation, adopters would have capital requirements that would range from 2.5 to 3.7 percentage points lower than the requirement for nonadopters for these types of mortgages, implying a cost of capital advantage ranging from 7 to 33 basis points. As we discussed earlier, however, this type of calculation fails to capture competitive effects on nonadopters because (1) on many of these mortgages the effective capital requirement would be lower than 4 percent, (2) depositories can lower effective capital requirements through securitization and blending, and (3) capital requirements are often not important factors in determining mortgage rates. Furthermore, to the extent that operating costs might be higher for adopters under Basel II than for nonadopters, the increased revenues captured from recouping deadweight losses might be partly or completely offset by these expenses. 
Indeed, most near-prime mortgages are likely not affected by Basel I-type capital requirements. First, as indicated in figure 4, an estimated 2.2 million of the 5.9 million near-prime mortgages are fixedrate, securitized mortgages (the middle light gray shaded box) and thus are not directly affected by capital rules on depositories. Second, about 3 million mortgages in this market carry adjustable interest rates; and as we have discussed, depositories value these ARMs for their interest rate characteristics and the capital charges on their credit risk are unlikely affect their pricing. Of the roughly 6 million mortgages in the near-prime market segment, only some (we estimate about 0.7 million) of the fixed-rate, nonsecuritized mortgages might fall in the region where regulatory capital constraints influence capital costs.

Adopters might have some capital savings for nonsecuritized, fixed-rate, near-prime mortgages currently held on portfolio, but without knowing why the depository ignored the incentives built into the Basel I capital regulations, we cannot predict its fate under Basel II. For example, the mortgage may carry higher credit risk than its LTV and credit score would suggest and thus is backed with prudent economic capital. In such circumstances, the adopter would not have a capital advantage once Basel II is implemented.

As in the prime market, adopters in this market segment are likely to put downward pressure on credit guarantee fees, including GSE guarantee fees (as shown in the cross-hatched region between $q_{2}$ and $q_{3}$ in figure 3). As described earlier, since adopters will be able to hold capital more in line with prudent economic capital under Basel II, selling mortgages to the GSEs and through other securitization outlets will need to be motivated by reasons other than the arbitrage of capital regulations.

\subsection{Subprime Mortgages and Basel II Implementation}

Under Basel II, 57 percent of subprime mortgages would require capital in excess of 400 basis points (the shaded region in the subprime market in figure 6). Indeed, we estimate about 0.4 million of the 4.9 million outstanding subprime loans would require prudent economic capital of 800 basis points or more. In addition, because we believe that the constant asset correlation assumption of the Basel II framework is least applicable to mortgage loans of the highest credit risk, the Basel II requirements may be higher than depositories' own estimates of the amount of prudent economic capital needed to fund such loans. ${ }^{58}$ At first glance, then, high risk mortgages carry the lowest capital charge when they are held on the books of nonadopters. In practice, though, examiners may require depositories to hold extra capital against these risky mortgages.

In 2003, about 23 percent of currently outstanding subprime loans have both an LTV ratio greater than 90 percent and a credit score less than 660. Under the current supervisory framework, examiners might reasonably expect a depository to hold capital in excess of 4 percent, or even 8 percent, on such loans, with the excess depending on the institution's loss rates on mortgages, the quality and liquidity of 
the collateral securing the loans, and the quality of risk management and control processes in place at the depository. It is therefore plausible that some depositories that would remain under Basel I-type capital standards might be encouraged to hold more capital than would be required of adopters for loans in this portion of the subprime market. In this manner, adopters that invest in sophisticated risk-management systems would potentially have a competitive advantage over some nonadopters (those with inadequate control processes) even in the riskiest portion of the subprime mortgage market. The number of nonadopters that would be at a disadvantage, however, is likely to be very small because the vast majority of depositories receive supervisory ratings consistent with sound risk management and prudent underwriting standards.

Since most depositories that would remain subject to the current regulatory regime would be required to hold just 4 percent of capital for subprime loans, we estimate that only about 0.5 million subprime, fixed-rate, nonsecuritized mortgages would have lower capital backing under Basel II. Thus, overall, we do not foresee that Basel II will significantly influence mortgage rates in the subprime market.

\section{Sensitivity Analysis}

In this section, we consider how our estimates of the potential competitive effects from implementing of Basel II capital standards would change with respect to (1) a higher prudent economic capital standard, (2) more risk-based (as opposed to uniform) pricing in mortgage markets, and (3) decisions by managers of depositories to maintain a "well-capitalized" designation from bank and thrift supervisors. That is, we explore the adjustments to our conclusions that would follow from higher-thanpostulated capital positions at adopter institutions and more-sensitive mortgage pricing than we have assumed.

\subsection{What if our estimates of prudent economic capital are too low?}

The largest U.S. depositories typically maintain issuer ratings that are better than the BBB to Astandard that we use in our proxy for capital demanded by the marketplace (i.e., prudent economic capital). In fact, 18 of the 20 largest U.S. bank holding companies ranked by total assets had Standard and Poor's issuer ratings better than A- as of year-end 2004. Because a higher rating would require higher capital, adopters would hold more market-determined capital than we have estimated. ${ }^{59}$

If our proxy for prudent economic capital is systematically too low, then our estimates of the number of mortgages that adopters could profitably acquire at the expense of nonadopters and securitizers would be too high. The prudent economic capital demanded by the marketplace would be higher than the 4 percent required by regulators for a larger proportion of existing mortgages, so it would be less likely that current capital regulations are influencing the amount of capital held on the balance sheets of 
depositories. Analogously, the amount of prudent economic capital required would be less than 45 basis points for fewer of the prime mortgages than we estimated. As a result, there would be less competitive tension between the adopters and the nonadopters and between the adopters and the GSEs than we have estimated.

If we have systematically underestimated the amount of prudent economic capital, the implementation of Basel II capital standards would have even smaller competitive effects than we have predicted. Not only would there be no direct effect on the mortgage rate from the implementation of Basel II, but also the indirect effects would be smaller - adopters would have smaller potential increases in their profits from capturing the deadweight losses that occur under the current regulatory frameworks imposed on depositories and on securitizers.

\subsection{What if Mortgage Pricing is more Risk-Sensitive?}

In our analysis, we divided the U.S. mortgage market into three broad segments. While these segments capture much of the variation in credit risk priced by lenders, within the segments other characteristics of the mortgages, such as documentation status, often affect pricing. In the limit, it is possible in the future that each mortgage would be individually priced using every scrap of information available on the borrower and property. ${ }^{60}$

Even if such risk-sensitive pricing were to become pervasive after the implementation of Basel II, nonadopters would still be motivated to sell credit risk on loans whose regulatory capital exceeds their economic capital. Indeed, this strategy would be even more important if the price of each mortgage reflected the amount of capital that is demanded by the marketplace for its risk. Depositories would still structure portfolios so the capital held for regulatory capital requirements is consistent with the capital demanded by the marketplace (i.e., they would be motivated to blend lower-risk mortgage holdings with higher-risk mortgage holdings). Moreover, depositories would continue to hold the credit risk on mortgages where the regulatory capital is less than the capital demanded by the marketplace.

In addition, even under pervasive risk-based pricing, pricing on some mortgages would still be influenced by Basel I regulatory constraints. For example, there would likely be some mortgages along the credit risk continuum where a securitizer could not be found that would back the credit risk of the mortgage with prudent economic capital. Similarly, if risk-sensitive pricing became pervasive, there could be some prime conforming mortgages where the GSE regulatory capital requirement, equal to 45 basis points, would influence the costs of bearing credit risk and therefore mortgage rates.

Under Basel II and in a more risk-sensitive pricing environment than we assumed, in the extreme case it would be feasible for the interest rate on every mortgage to reflect its market-determined capital. That is, mortgage rates would reflect prudent economic capital throughout the credit risk continuum. If 
each mortgage was backed by prudent capital, some mortgage rates would fall (since current capital standards influence their rates). Thus, competitive markets for the provision of mortgages would ensure that mortgage borrowers—and not adopters—would be the long-run beneficiaries of Basel II.

\subsection{What if Depositories Desire to Maintain a "Well-Capitalized" Status?}

The Federal Deposit Insurance Corporation Improvement Act (FDICIA) of 1991 established the system of prompt corrective actions (PCA) to be taken with troubled insured depository institutions (other than credit unions). Under this system, risk-based capital ratios are used as a basis for categorizing depositories for purposes of prompt corrective action. "Well-capitalized" depositories are defined as those with a tier 1 risk-based ratio greater than 6 percent, a total risk-based capital ratio greater than 10 percent, and a tier 1 leverage ratio greater than 5 percent. $^{61}$

The PCA system imposes more penalties on undercapitalized depositories as their capital ratios decline, including restrictions on deposit interest rates, elimination of brokered deposits, restrictions on asset growth, restrictions on inter-affiliate transactions, and required approvals for acquisitions, branching, and new activities. Although bank and thrift holding companies are not subject to the PCA system, bank holding companies are subject to minimum consolidated capital guidelines.

The fairly severe penalties associated with being designated as undercapitalized by bank or thrift supervisors could potentially increase depositories' desire to hold capital above either prudent economic or regulatory capital. As discussed in section 2.4, a reduction in a depository institution's minimum regulatory capital requirement may not change the depository institution's actual capitalization under such circumstances. Without the replacement of some equity holdings with debt financing, the implementation of Basel II capital standards would $a$ fortiori lead to smaller competitive effects than we have estimated.

After implementation of the Basel II framework, adopters and nonadopters alike would continue to be subject to PCA, regardless of whether the insured entities are banks or thrifts. To achieve "wellcapitalized” status, for example, a depository would need to maintain at least a five percent tier 1 leverage ratio. $^{62}$ It is therefore plausible that depositories might target a leverage ratio in excess of this minimum. If such targets influence adopters' decisions at the margin, Basel II implementation would have smaller competitive effects than we have projected. Under such circumstances, adopters would behave much like nonadopters to meet or exceed the risk-insensitive mortgage capital requirements that are the hallmark of current capital standards.

\subsection{Sensitivity Analysis Findings}

Because higher prudent economic capital estimates, more risk-sensitive mortgage pricing, and greater significance of PCA standards would each reduce, not increase, the potential competitive effects 
of Basel II implementation on mortgage markets, it is probable that we have overstated, not understated, such effects. Moreover, it is clear that developments in mortgage markets (such as more risk-sensitive pricing), innovations by depositories (such as more complex securitization techniques), and competition between adopters may dissipate any potential supernormal profits earned by adopters under Basel II.

\section{Conclusion}

It seems unlikely that Basel II implementation will have significant effects on U.S. residential mortgage market competition between adopters and nonadopters. Our analysis indicates that most mortgages are already backed by market-determined capital needs because depositories use GSE guarantees and other forms of securitizations, as well as blending high- and low-risk mortgage portfolios to equate regulatory and economic capital under the current one-size-fits-all capital regulations. Basel II will increase the risk sensitivity of regulatory capital charges; effectively, however, the actual capital backing mortgages is already quite sensitive to their credit risk. Moreover, in the future, adopters and nonadopters alike will continue to be subject to risk-insensitive capital regulations like leverage requirements, and consequently these institutions will continue to blend mortgages with other assets and to be conservative in their capital management.

Our results are robust to relaxing several of our key assumptions. In particular, the competitive impact of Basel II will be lower if (1) adopters seek a better credit agency rating than we assumed, (2) risk-based pricing in mortgage markets is more pervasive than we assumed, or (3) the system of prompt corrective actions impinges on depositories’ decision-making more than we have assumed.

Indeed, potential income gains from capital cost savings may in the long run flow not to adopters, but to homeowners through lower mortgage rates. 


\section{References}

Ambrose, B., M. LaCour-Little, and A. Sanders, 2004, "Does Regulatory Arbitrage or Asymmetric Information Drive Securitization?,” Paper presented at the XII International Tor Vergata Conference on Banking and Finance

Avery, R., R. Bostic, P. Calem, and G. Canner, 2000, "Credit Scoring: Statistical Issues and Evidence from Credit Bureau Files,” Real Estate Economics, 28, pp. 523-47.

Avery, R.B., P.S. Calem, and G.B. Canner, 2004, “Credit Report Accuracy and Access to Credit, Federal Reserve Bulletin, Summer, pp. 297-322.

Bannock, G., R. Baxter, and E. Davis, 2003, Dictionary of Economics, Bloomberg Press: Princeton, N.J.

Barakova, I., R. Bostic, P.S. Calem, and S. Wachter, 2003, "Does Credit Quality Matter for Homeownership?” Journal of Housing Economics, 12, pp. 318-36.

Basel Committee on Banking Supervision, 2004, International Convergence of Capital Measurement and Capital Standards: A Revised Framework, Bank for International Settlements: Basel Switzerland, June.

Calem, P.S. and J.R. Follain, 2003, "The Asset -Correlation Parameter in Basel II for Mortgages on Single-Family Residences,” Working Paper, Board of Governors of the Federal Reserve System, November 6.

Calem, P.S. and J.R. Follain, 2005, “An Examination of How the Proposed Bifurcated Implementation of Basel II in the U.S. May Affect Competition among Banking Organizations for Residential Mortgages,” Working Paper posted on ABA.com, January 14.

Calem, P.S. and M. LaCour-Little, 2004, "Risk-based Capital Requirements for Mortgage Loans," Journal of Banking and Finance, 28, pp. 647-72.

Canner, G. and W. Passmore, 1996, "Distribution of Credit Risk among Providers of Mortgages to Lower-Income and Minority Homebuyers,” Federal Reserve Bulletin, December.

Canner G., E. Laderman, and W. Passmore, 1999, "The Role of Specialized Lenders in Extending Mortgages to Lower Income and Minority Homebuyers,” November, Federal Reserve Bulletin, 85: 11, pp. 709-26.

Congressional Budget Office, 2003, Effects of Repealing Fannie Mae's and Freddie Mac's SEC Exemptions,” May.

Cotterman, R., 2004, “Analysis of FHA Single-Family Default and Loss Rates,” U.S. Department of Housing and Urban Development, March.

Cutts, A.C., R.A. Van Order, and P.M. Zorn, 2001, “Adverse Selection, Licencing, and the Role of Securitization in Financial Market Evolution and Pricing,” Working Paper, Freddie Mac.

DeMarzo, P.M. (2004), “The Pooling and Tranching of Securities: A Model of Informed Intermediation,” Review of Financial Studies, forthcoming. 
Downing, C., D. Jaffee, and N. Wallace, 2004, "Information Asymmetries in the Mortgage Backed Securities Market,” Working Paper, Rice University, Houston TX.

Duca, J.V. and S.S. Rosenthal, 1994, "Do Mortgage Rates Vary Based on Household Default Characteristics? Evidence on Rate Sorting and Credit Rationing,” Journal of Real Estate Finance and Economics, 8, pp. 99-113.

Edelberg, W., 2003, "Risk-based Pricing of Interest Rates in Household Loan Markets,” FEDS Working Paper Series, 2003-62, December 5.

Federal Financial Analytics, Inc., 2004, “Basel Bubbles Mean Toil and Trouble,” GSE Activity Report, August 10.

Federal Reserve Board, 1999, “Interagency Guidance on High LTV Residential Real Estate Lending,” Banking Supervision and Regulation SR Letter 99-26, October 8.

Federal Reserve Board, 2001, "Expanded Guidance for Subprime Lending Programs,” Banking Supervision and Regulation SR Letter 01-4, January 31.

Frame, W.S. and L.J. White, 2004a, “Competition for Fannie Mae and Freddie Mac?” Regulation, Fall.

Frame, W.S. and L.J. White, 2004b, "Emerging Competition and Risk-Taking Incentives at Fannie Mae and Freddie Mac,” Working Paper 2004-4, Federal Reserve Bank of Atlanta, February.

Gates, S.W., V.G. Perry, and P.M. Zorn, 2002, “Automated Underwriting in Mortgage Lending: Good News for the Underserved?” Housing Policy Debate, 13, pp. 369-89.

Gordy, M., 2003, “A Risk-Factor Model Foundation for Ratings-based Capital Rules,” Journal of Financial Intermediation, 12, pp. 199-32.

Hancock, D., A. Lehnert, W. Passmore, and S. Sherlund, 2005, “An Analysis Of The Potential Competitive Impacts Of Basel II Capital Standards On U.S. Mortgage Rates And Mortgage Securitization.” White paper, Federal Reserve Board, http://www.federalreserve.gov/GeneralInfo/Basel2/docs2005/potentialimpact.pdf

Heuson, A., W. Passmore, and R. Sparks, 2001, "Credit Scoring and Mortgage Securitization: Implications for Mortgage Rates and Credit Availability,” Journal of Real Estate Finance and Economics, 23, pp. 337-63.

Independent Community Bankers of America, 2003, "ICBA to Agencies: Ensure Competitive Equity Under Basel II,” press release, November 5.

Inside Mortgage Finance, 2004, The 2004 Mortgage Market Statistical Annual, Bethesda, MD: Inside Mortgage Finance Publications, Inc.

Jones, D. and J. Mingo, 1999, "Credit Risk Modeling and Internal Capital Allocation Processes: Implications for Models-Based Regulatory Bank Capital Standard,” Journal of Economics and Business, 51, pp. 79-108.

Jones, D., 2000, "Emerging Problems with the Basel Capital Accord: Regulatory Capital Arbitrage and Related Issues,” Journal of Banking and Finance, 24, pp. 35-56. 
Kaskowitz, D., A. Kipkalov, K. Lundstedt, and J. Mingo, 2002, "Best-Practices in Mortgage Default Risk Measurement and Economic Capital,” The RMA Journal, June.

Kupiec, P., 2005, "Unbiased Capital Allocation in an Asymptotic Single Risk Factor (ASRF) Model of Credit Risk, FDIC Center for Financial Research Working Paper No. 2005-04.

Macomber, M.E., 2004, “Regulatory Relief for Community-Based Banks,” Congressional Testimony, May 12.

Mingo, J., 2000, "Policy Implications of the Federal Reserve Study of Credit Risk Models at Major US Banking Institutions,” Journal of Banking and Finance, 24, pp. 15-33.

Modigliani, F. and M.H. Miller, 1958, "The Cost of Capital, Corporation Finance, and the Theory of Investment, American Economic Review, 48, pp. 261-97.

Myers, S.C. and N. Majluf, 1984, "Corporate Financing and Investment Decisions when Firms Have Information that Investors do not Have,” Journal of Financial Economics, 13, pp. 187-221.

National Economic Consulting (NEC), 2004, “Assessing the Subprime Market,” Prepared for the Coalition for Fair and Affordable Lending, May.

Office of Federal Housing Enterprise Oversight, 2004, “Report to Congress,” June 15.

Passmore, W., 1994, "The Influence of Risk-Adjusted Capital Regulations on Asset Allocation by Savings and Loans,” Global Risk Based Capital Regulations, Volume II, Edited by Charles Stone and Anne Zissu, Irwin Professional Publishing: New York, New York.

Passmore, W and Roger Sparks (1996). "Putting the Squeeze on the Market for Lemons: GovernmentSponsored Mortgage Securitization," Journal of Real Estate Finance and Economics, 13, pp. 2743.

Pennington-Cross, A., A. Yezer, and J. Nichols, 2000, "Credit Risk and Mortgage Lending: Who Uses Subprime and Why?” Research Institute for Housing America, Working Paper No. 00-03, September.

Raiter F.L. and F. Parisi, 2004, “Mortgage Credit and the Evolution of Risk-Based Pricing,” Joint Center for Housing Studies, Harvard University, Working Paper BABC 04-23, February 13.

Sharpe, S., 2002, "Reexamining Stock Valuation and Inflation: The Implications of Analyst's Earning Forecasts,” The Review of Economics and Statistics, 84, 632-48.

Simensen, I., 2004, “Banks Could Face Ratings Cuts, Warns S\&P,” Financial Times, October 21.

Standard \& Poor’s, 2004, “Basel II: Evolution not Revolution for Banks,” October 4.

Steinbach, G.H., 1998, “Making Risk-Based Pricing Work,” Mortgage Banking, 58, pp.10-19.

Stiglitz, J. and A. Weiss, 1981, “Credit Rationing in Markets with Imperfect Information,” Journal of Finance, 43, pp. 375-96. 


\section{Figure 1: Economic Capital Concepts}

Basel II Regulatory Capital Requirements for Whole Loans

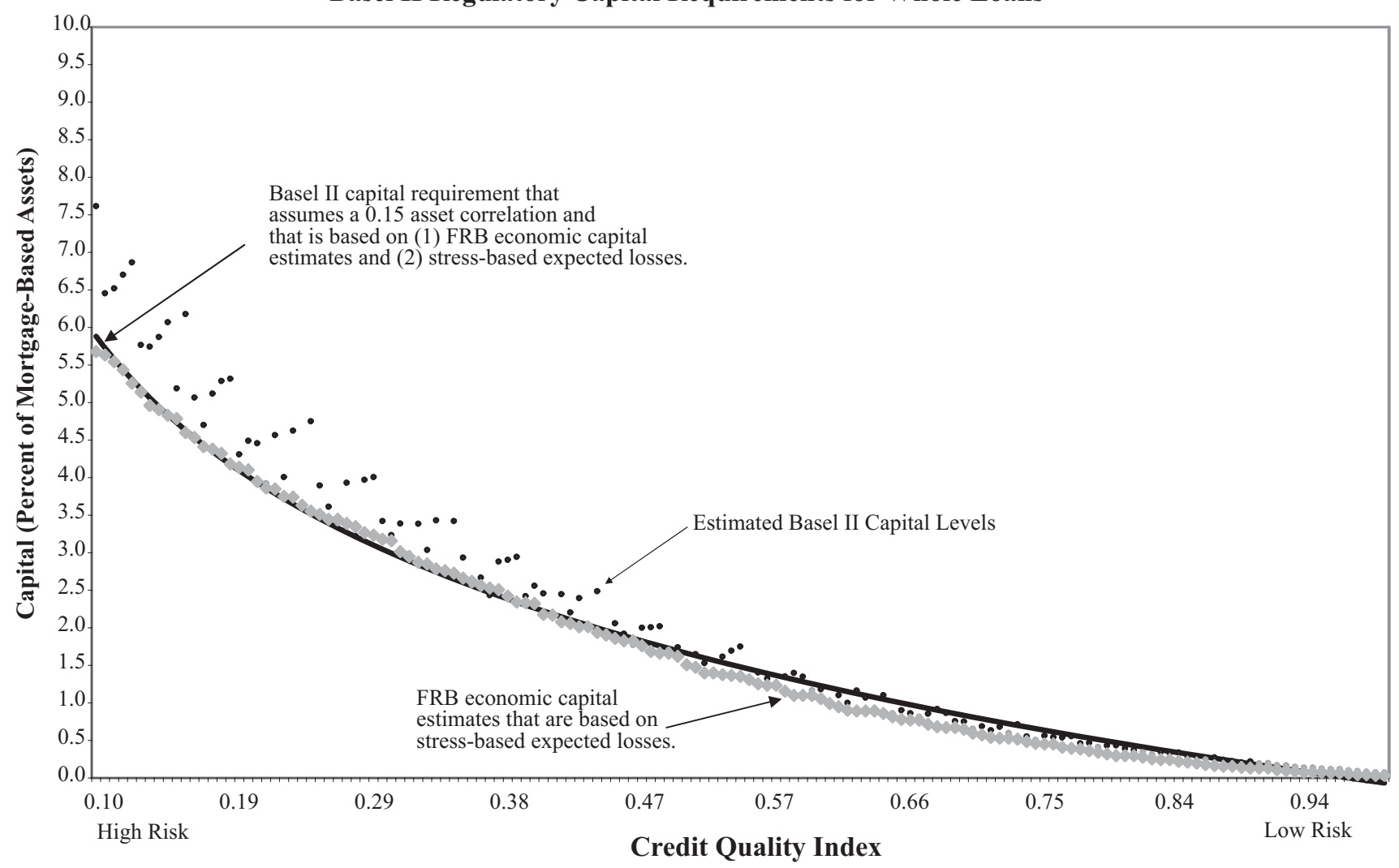

\section{Comparison of Regulatory Capital Requirements under Basel I and Basel II} with GSE Capital Requirement for Credit Risk, and Prudent Capital

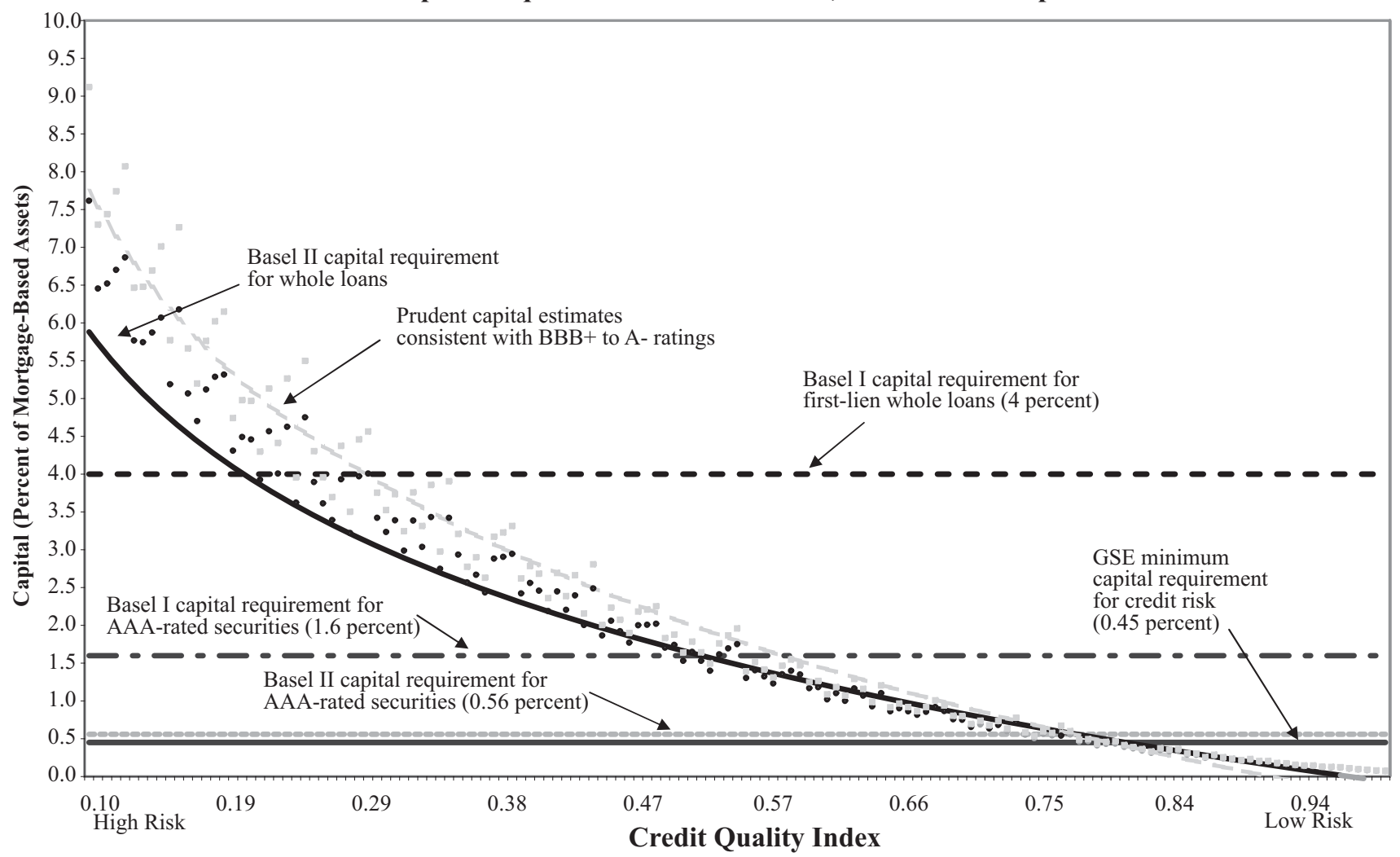

Note: The credit quality index equals 1 for the lowest risk credit score-LTV pair and approaches 0 for the credit score-LTV pair with the highest risk using the FRB credit risk model's estimates of economic capital. 
Figure 2

\section{Mortgage Funding Cost Curves}

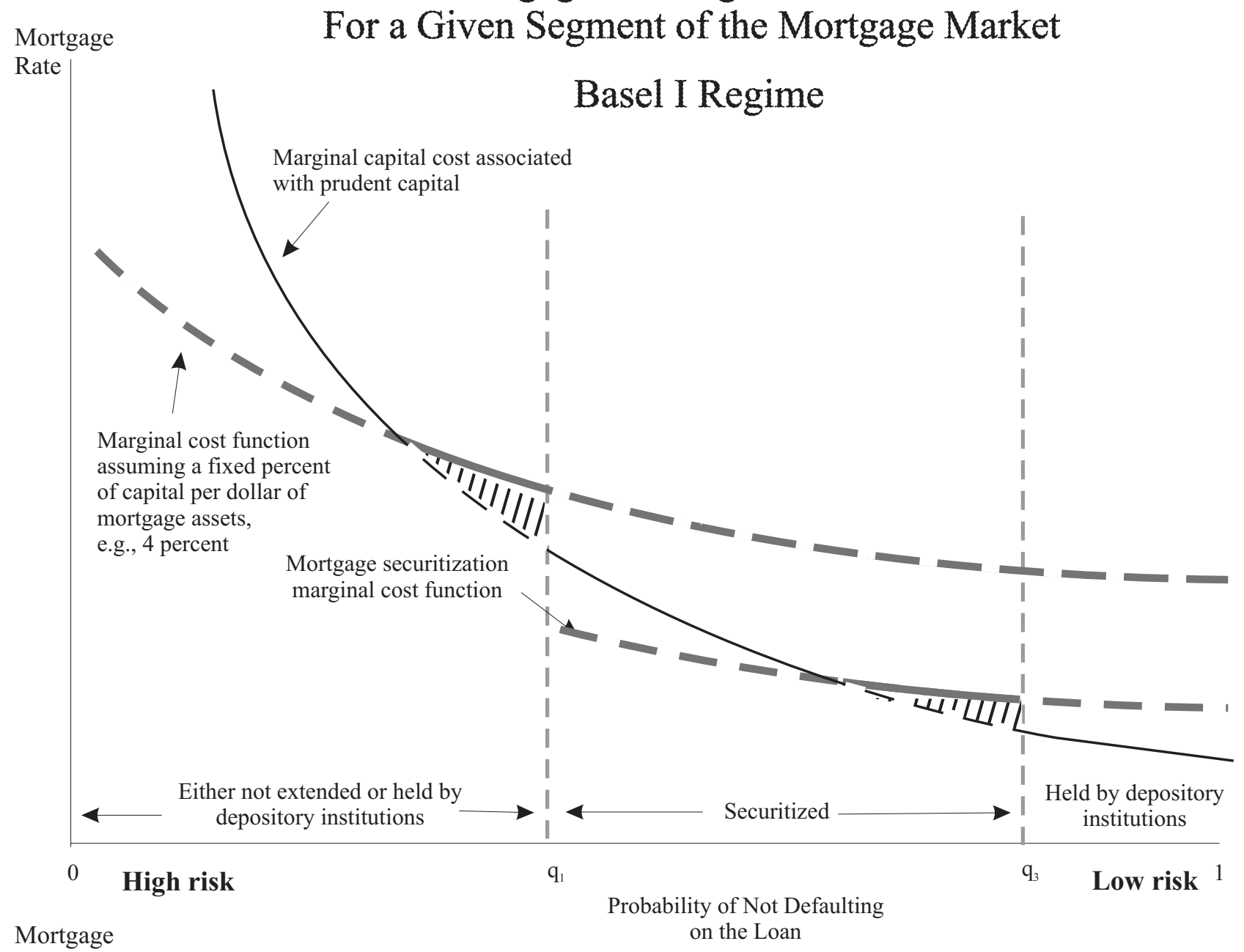

Rate

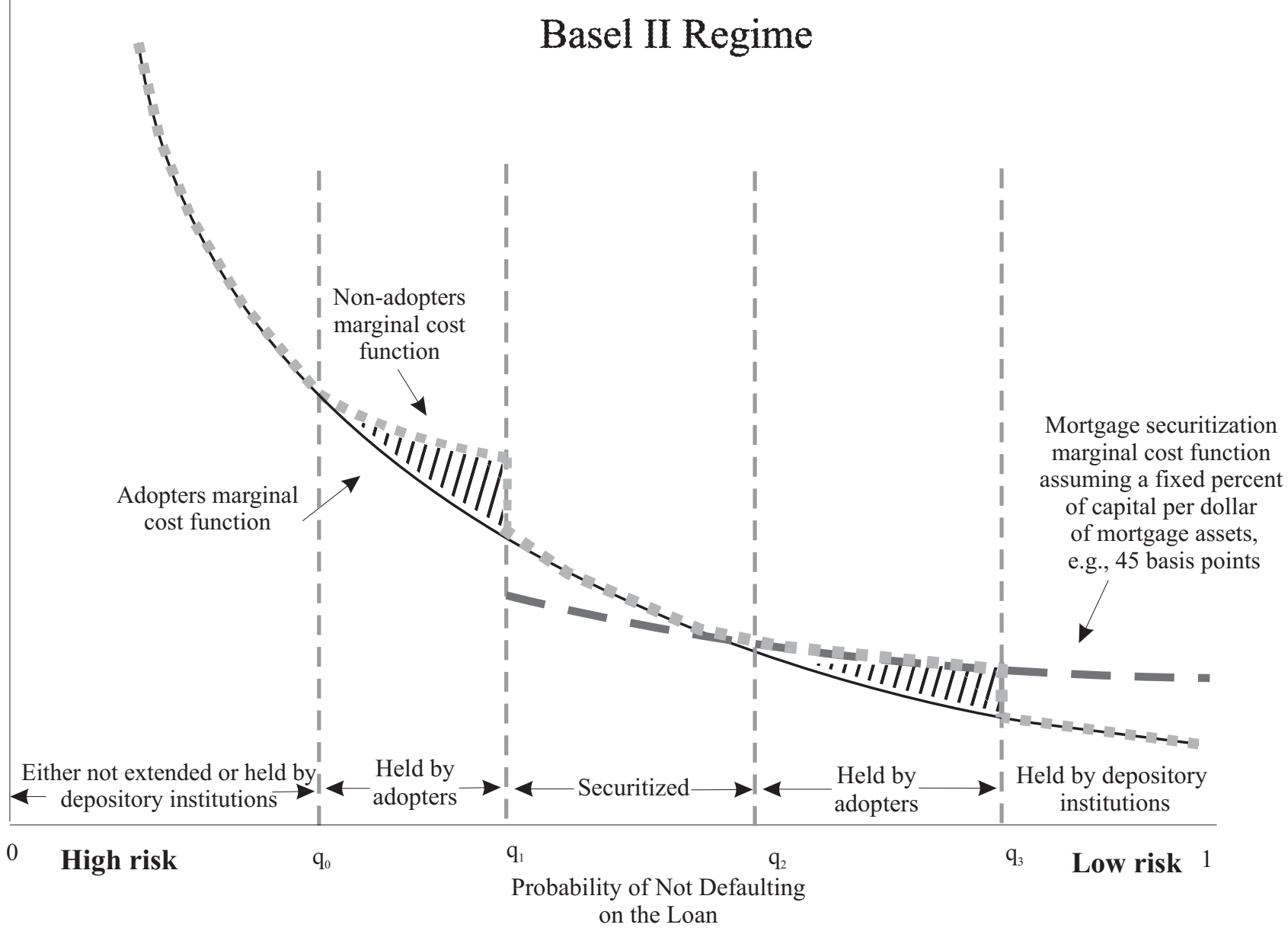


Figure 3

Possible Equilibria in a Given Segment of the Mortgage Market

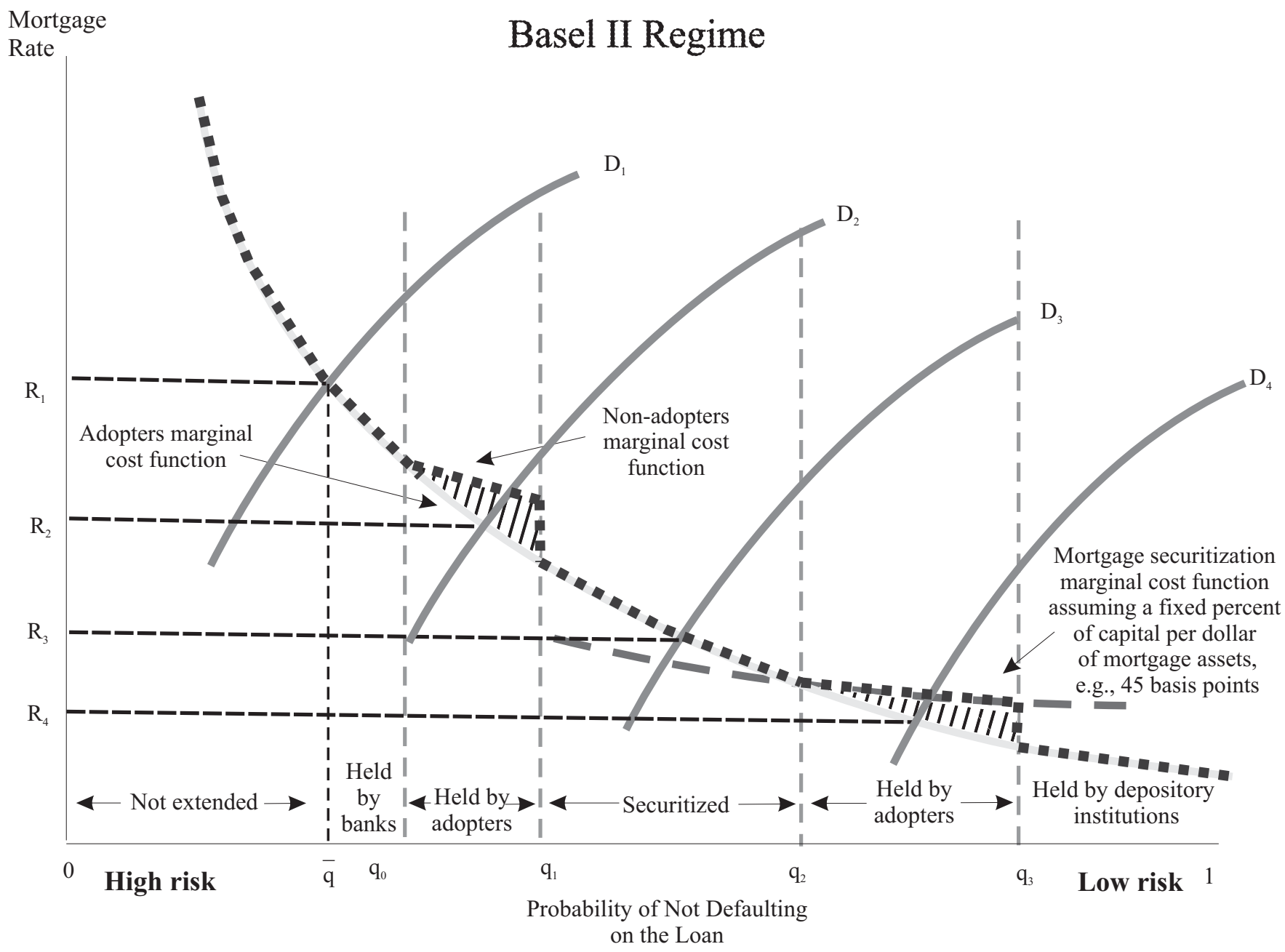




\section{Figure 4 \\ Description of U.S. First-Lien Conventional Mortgage Market as of 2003:Q3 \\ Millions of Loans \\ (Percent of Loan Amount Securitized)}

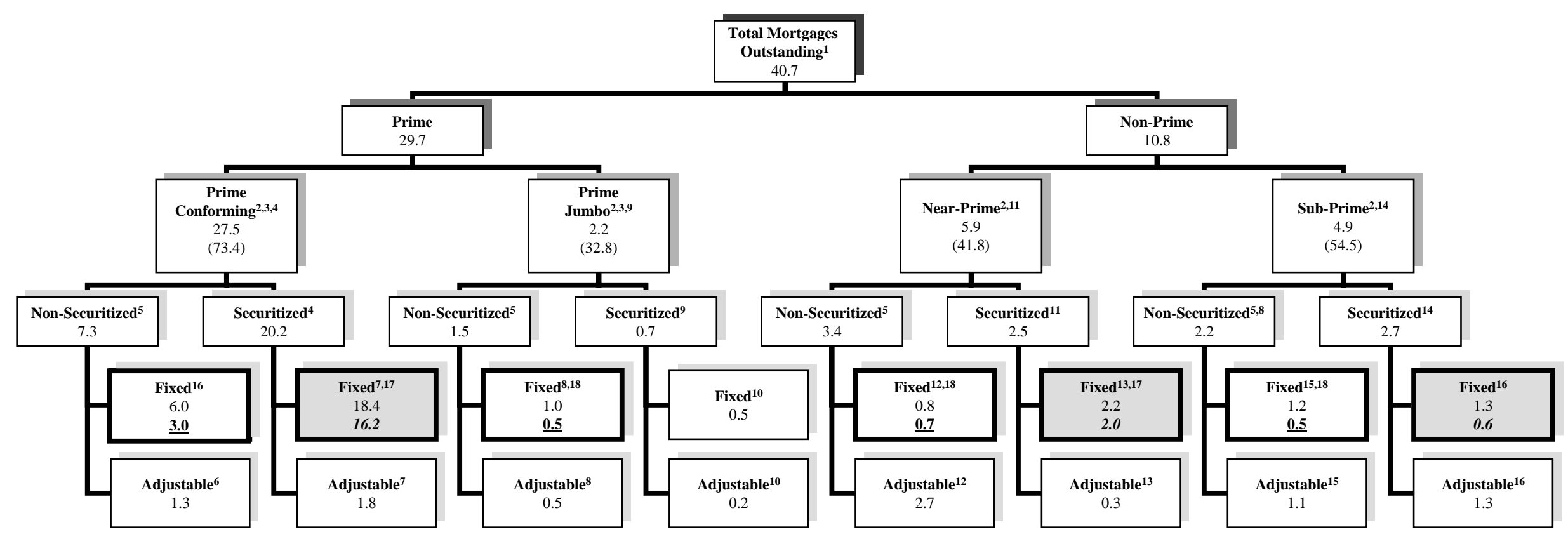

* Components may not sum to totals because of rounding. The italicized numbers are our estimates of the maximum number of loans contested by adopters and securitizers over a long period after the implementation of the proposed Basel II regulatory capital framework. The underlined numbers represent our estimates of the maximum number of loans contested by adopters and non-adopters over a long period after Basel II implementation. 


\section{Footnotes \\ Figure 4: Description of U.S. First-Lien Conventional Mortgage Market as of 2003:Q3}

1. The total number of mortgages outstanding is calculated by dividing the level of first-lien conventional mortgage debt from the 2003:Q3 Flow of Funds Accounts by the average loan size from the September 2003 LoanPerformance (LP) prime and subprime data. First-lien conventional mortgage debt is household home mortgages (Table L.218, line 2) minus FHA/VA loans (U.S. Department of Housing and Urban Development and Veteran’s Administration) minus 2nd Liens (Table L.218, line 24).

2. Prime, near-prime, and subprime splits are calculated using the 2001 SCF, 2001 Residential Finance Survey (RFS), FICO distributions from 2003 Credit Bureau data, and LTV distributions from the September 2003 LP prime and subprime data.

3. The split between the number of prime conforming and prime jumbo is the percentage of conforming and jumbo loans with prime characteristics from the 2001 RFS (92.5\% conforming and 7.5\% jumbo) applied to the calculated number of prime loans.

4. The percent of securitized prime conforming loans is a 3-year average (2001-2003) securitization rate for Fannie/Freddie from the 2004 Mortgage Market Statistical Annual. This securitization rate is percent of loan value.

5. The number of non-securitized loans is the total number of loans minus the securitized loans.

6. From the 2001 RFS, $88.6 \%$ of non-jumbo loans that have prime characteristics are fixed-rate and $11.4 \%$ are ARMs. Thus, the number of non-securitized prime fixed-rate conforming loans is the total number of prime fixed-rate conforming loans $(0.886 \cdot 27.5=24.4)$ minus the number of securitized prime fixed-rate conforming loans (18.4). The number of non-securitized prime ARM conforming loans is the total number prime ARM conforming loans $(0.114 \cdot 27.5=3.1)$ minus the number of securitized prime ARM conforming loans (1.8).

7. Fannie Mae reports in its 2003 annual report that $9 \%$ of its mortgages are ARMs and $91 \%$ are fixed-rate. These percentages are applied to the total number of securitized conforming prime loans.

8. From the 2001 RFS, $70.0 \%$ of jumbo loans that have prime characteristics are fixed and $30.0 \%$ are ARMs. Thus, the number of nonsecuritized prime fixed-rate jumbo loans is the total number of prime fixed-rate jumbo loans $(0.7 \cdot 2.2=1.5)$ minus the number of securitized prime fixed-rate jumbo loans (0.5). The number of non-securitized prime ARM jumbo loans is the total number of ARM jumbo loans $(0.3 \cdot 2.2=0.7)$ minus the number of securitized prime ARM jumbo loans $(0.2)$.

9. The percent of securitized prime jumbo loans is a 3-year average (2001-2003) securitization rate for jumbo loans from the 2004 Mortgage Market Statistical Annual.

10. From the January 2004 LP Securities Coverage Report, $76.2 \%$ of securitized jumbo loans are fixed and $23.8 \%$ are ARMs. These percentages are applied to the total number of securitized jumbo loans.

11. The percent of securitized near-prime loans is calculated by dividing annual A- issuance volume from Inside MBS/ABS by Aorigination volume from the LP subprime database and taking a 3-year average (2001-2003) of the securitization rate. The LP origination volume is blown up to reflect the entire market; the fraction of A- loans in the LP subprime database is then applied to the entire market to estimate the near-prime loan origination volume.

12. From the September 2003 LP subprime database, $50.0 \%$ of near-prime loans are fixed and $50.0 \%$ are ARMs. Thus, the number of non-securitized near-prime fixed-rate loans is the total number of near-prime fixed-rate loans $(0.5 \cdot 5.9=3.0)$ minus the number of securitized near-prime fixed-rate loans (2.2). The number of non-securitized near-prime ARM loans is the total number of near-prime ARM loans $(0.5 \cdot 5.9=3.0)$ minus the number of securitized near-prime ARM loans $(0.3)$.

13. From the January 2004 LP Securities Coverage Report, $89.6 \%$ of near-prime loans are fixed and $10.4 \%$ are ARMs. These percentages are applied to the total number of securitized near-prime loans.

14. The percent of securitized subprime loans is calculated by dividing annual issuance volume from the 2004 Mortgage Market Statistical Annual by subprime origination volume from the LP subprime database and taking a 3-year average (2001-2003) of the securitization rate. The LP origination volume is blown up to reflect the entire market.

15. From the September 2003 LP subprime database, $51.1 \%$ of subprime loans are fixed and $48.9 \%$ are ARMs. Thus, the total number of non-securitized subprime fixed-rate loans is the total number of subprime fixed-rate loans $(0.511 \cdot 4.9=2.5)$ minus the number of securitized subprime fixed-rate loans (1.3). The number of non-securitized subprime ARM loans is the total number of subprime ARM loans $(0.489 \cdot 4.9=2.4)$ minus the number of securitized subprime ARM loans $(1.3)$.

16. From the January 2004 LP Securities Coverage Report, $50.0 \%$ of subprime loans are fixed and $50.0 \%$ are ARMs. These percentages are applied to the total number of securitized subprime loans.

17. About 88 percent of prime mortgages are estimated to require an economic capital backing of less than 45 basis points. We apply this fraction to the outstanding 18.4 million of fixed-rate mortgages that have been currently securitized to get 16.2 million. Similarly, 91 percent of the near-prime securitized fixed-rate mortgages require prudent capital of less than 4 percent, suggesting that up to 2.0 million of these 2.2 million mortgages might be contested by adopters and securitizers. Finally, 44 percent of the subprime securitized fixed-rate mortgages have economic capital that fall under 4 percent, suggesting adopters and securitizers might contest up to .6 million of these 1.3 million mortgages.

18. To estimate the number of blended mortgages, we look at the capital surplus of the subprime fixed-rate mortgages (the difference between the economic capital and 4 percent) and derive the percent of prime fixed-rate mortgages (with a prudent capital of less than 4 percent) that might be funded with this surplus. For example, if a subprime mortgage has a surplus of 1.2 percent and prime mortgages require 30 basis points of economic capital, then with constant dollar amounts four prime mortgages can be backed by holding one subprime mortgage. Our calculations are very rough and aggregated, and suggest that about half of the fixed-rate prime mortgages are blended but that almost none of the near-prime and subprime mortgages are blended (because we assume that mortgages with the least amount of capital are blended first, this assumption may be unrealistic for individual institutions because they might specialize in a market segment). Thus, under these assumptions we get an upper-bound for our estimate of contested mortgages for the fixed-rate non-securitized mortgages in the near-prime and subprime markets. (The only mortgages not contested are those that require more than 4 percent prudent capital.) 
Figure 5

Median Estimated Prudent Capital

(Basis Points)

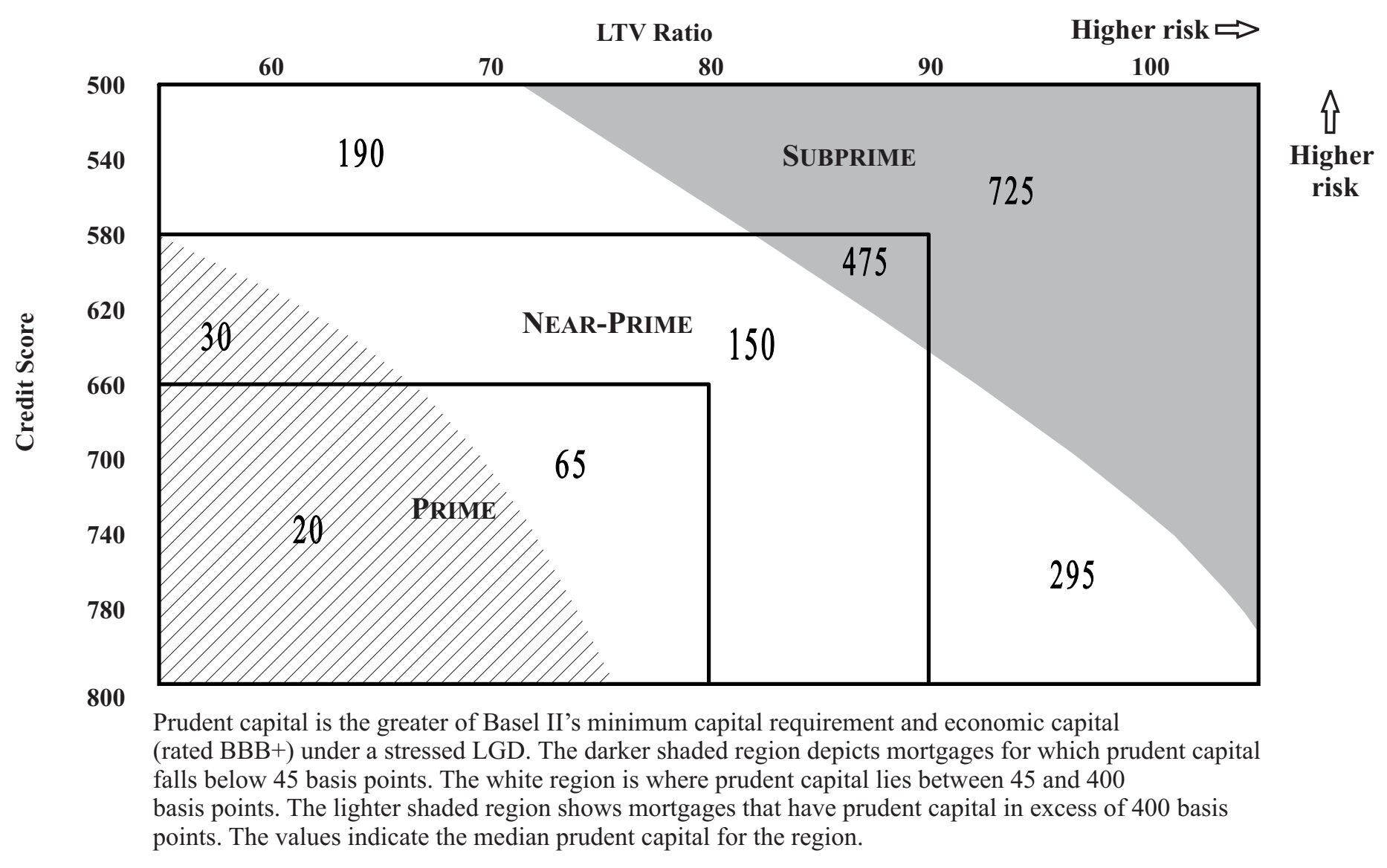


Figure 6

Distribution of Mortgages

(Percent of Loans per Market Segment)

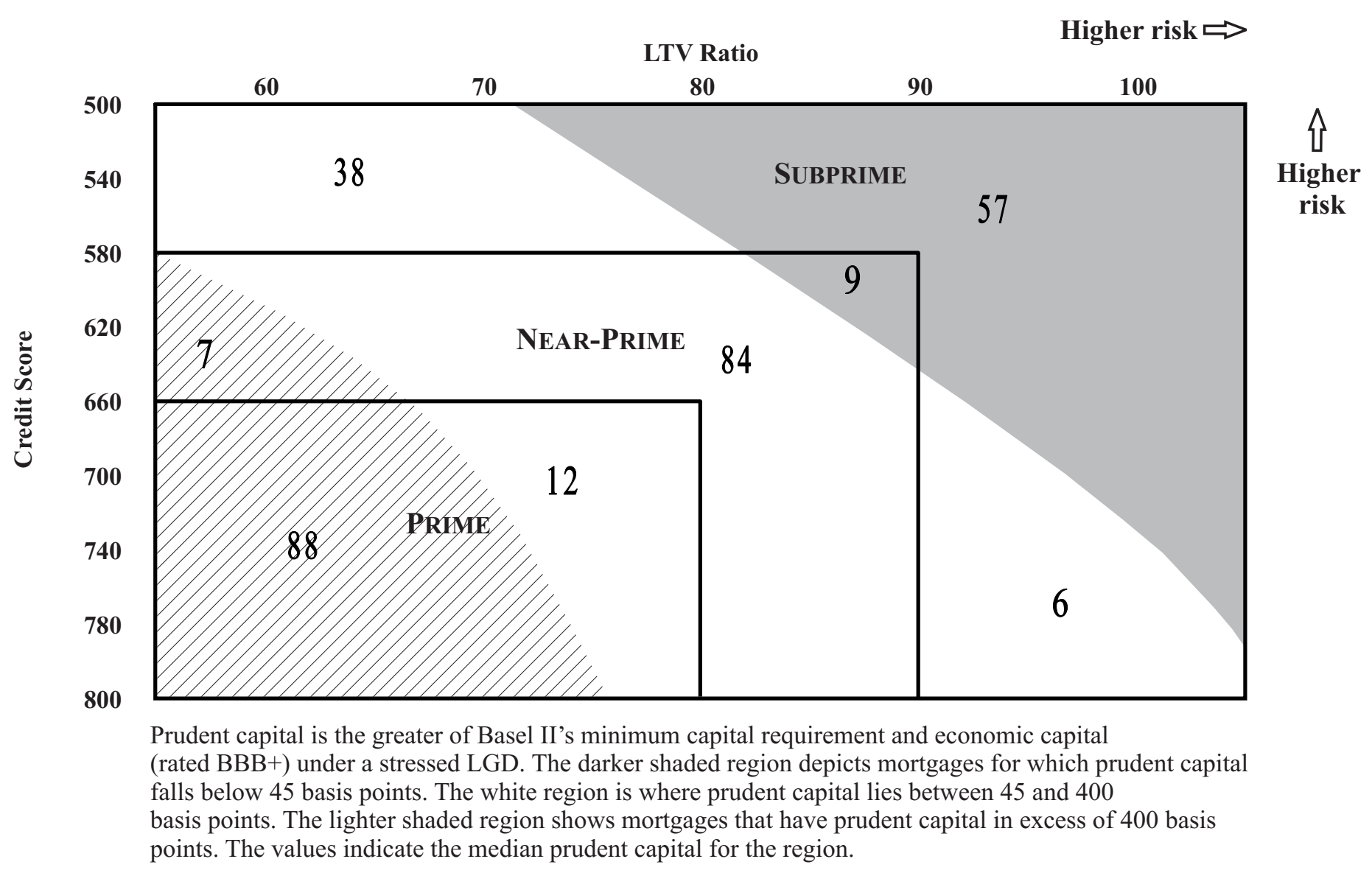




\section{Table 1}

Basel I Risk-Weights for Externally Rated Long-term Positions

\begin{tabular}{|l|c|c|}
\hline \multicolumn{1}{|c|}{ RATING CATEGORY } & $\begin{array}{c}\text { RATING DESIGNATION } \\
\text { EXAMPLES }\end{array}$ & $\begin{array}{c}\text { RISK WEIGHT } \\
\text { (in percent) }\end{array}$ \\
\hline \hline Highest or second-highest investment grade & AAA, AA & 20 \\
Third highest investment grade & A & 50 \\
Lowest investment grade & BBB & 100 \\
One category below investment grade & BB & 200 \\
\hline
\end{tabular}

\section{Basel II Risk-weights for External Rating Grades}

\section{or Available Inferred Ratings for Long-term Positions}

\begin{tabular}{|c|c|c|}
\hline $\begin{array}{l}\text { LONG-TERM CREDIT RATING AND/OR } \\
\text { INFERRED RATING DERIVED FROM A LONG- } \\
\text { TERM ASSESSMENT }\end{array}$ & $\begin{array}{l}\text { RISK-WEIGHT FOR SENIOR } \\
\text { POSITIONS } \\
\text { (in percent) }\end{array}$ & $\begin{array}{l}\text { BASE RISK WEIGHTS USED FOR } \\
\text { NON-SENSITIVE POSITIONS } \\
\text { (in percent) }\end{array}$ \\
\hline$(1)$ & $(2)$ & (3) \\
\hline AAA & 7 & 12 \\
\hline AA & 8 & 15 \\
\hline $\mathrm{A}^{+}$ & 10 & 18 \\
\hline A & 12 & 20 \\
\hline A- & 20 & 35 \\
\hline $\mathrm{BBB}+$ & 35 & 50 \\
\hline BBB & 60 & 75 \\
\hline BBB- & \multicolumn{2}{|c|}{100} \\
\hline $\mathrm{BB}+$ & \multicolumn{2}{|c|}{250} \\
\hline BB & \multicolumn{2}{|c|}{425} \\
\hline BB- & \multicolumn{2}{|c|}{650} \\
\hline Below BB- and unrated & \multicolumn{2}{|c|}{ Deduction } \\
\hline $\begin{array}{l}\text { Source: Basel Committee on Banking Super } \\
\text { percent from tier } 1 \text { and } 50 \text { percent } \mathrm{f}\end{array}$ & $\begin{array}{l}\text { (2004, pp. 128-129). Dedu } \\
\text { er } 2 \text { capital. }\end{array}$ & ns of investments will be 50 \\
\hline
\end{tabular}


Table 2: Liability Structure of Bank Holding Companies in the United States

(Rankings by Asset Size are Computed as of 2003)

\begin{tabular}{|c|c|c|c|c|c|c|}
\hline \multirow[b]{2}{*}{$\begin{array}{l}\text { BANK HOLDING COMPANY SIZE } \\
\text { Balance Sheet Items }\end{array}$} & \multicolumn{2}{|c|}{1999} & \multicolumn{2}{|c|}{2001} & \multicolumn{2}{|c|}{2003} \\
\hline & $\begin{array}{c}\text { Billions of } \\
\text { Dollars }\end{array}$ & \begin{tabular}{|c}
$\begin{array}{c}\text { Percent of } \\
\text { Total } \\
\text { Assets }\end{array}$ \\
\end{tabular} & $\begin{array}{c}\text { Billions of } \\
\text { Dollars }\end{array}$ & \begin{tabular}{|c|}
$\begin{array}{c}\text { Percent of } \\
\text { Total } \\
\text { Assets }\end{array}$ \\
\end{tabular} & $\begin{array}{c}\text { Billions of } \\
\text { Dollars }\end{array}$ & 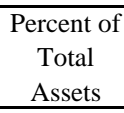 \\
\hline \multicolumn{7}{|l|}{10 LARGEST } \\
\hline \multicolumn{7}{|l|}{ Total Liabilities } \\
\hline Core Deposits * & 899 & 30 & 1199 & 30 & 1387 & 30 \\
\hline Managed Liabilities * & 1401 & 47 & 1816 & 45 & 2138 & 46 \\
\hline Other & 447 & 15 & 693 & 17 & 773 & 16 \\
\hline Total Equity Capital & 212 & 7 & 289 & 7 & 328 & 7 \\
\hline Total Assets & 3011 & 100 & 4048 & 100 & 4695 & 100 \\
\hline \multicolumn{7}{|l|}{ NEXT 10 LARGEST } \\
\hline Core Deposits * & 244 & 36 & 300 & 37 & 345 & 36 \\
\hline Managed Liabilities * & 267 & 39 & 287 & 35 & 337 & 35 \\
\hline Other & 37 & 5 & 58 & 7 & 68 & 7 \\
\hline Total Equity Capital & 50 & 7 & 65 & 8 & 82 & 9 \\
\hline Total Assets & 675 & 100 & 817 & 100 & 957 & 100 \\
\hline \multicolumn{7}{|l|}{ NEXT 30 LARGEST } \\
\hline Core Deposits * & 297 & 42 & 360 & 42 & 418 & 41 \\
\hline Managed Liabilities * & 239 & 34 & 269 & 31 & 314 & 31 \\
\hline Other & 22 & 3 & 61 & 7 & 68 & 7 \\
\hline Total Equity Capital & 56 & 8 & 80 & 9 & 97 & 10 \\
\hline Total Assets & 706 & 100 & 864 & 100 & 1015 & 100 \\
\hline \multicolumn{7}{|c|}{ ALL OTHER REPORTING BANK HOLDING } \\
\hline \multicolumn{7}{|c|}{ COMPANIES } \\
\hline Total Liabilities & & & & & & \\
\hline Core Deposits * & 840 & 51 & 818 & 49 & 989 & 47 \\
\hline Managed Liabilities * & 510 & 31 & 382 & 23 & 542 & 26 \\
\hline Other & 126 & 8 & 277 & 17 & 355 & 17 \\
\hline Total Equity Capital & 128 & 8 & 143 & 9 & 185 & 9 \\
\hline Total Assets & 1639 & 100 & 1656 & 100 & 2115 & 100 \\
\hline
\end{tabular}

Source: Bank Holding Company Consolidated Reports and bank Call Reports as of December 31.

* Bank holding company information derived as the sum of subsidiary bank data. Core deposits consist of transactions deposits, savings accounts, and small time deposits. Managed liabilities mainly consist of deposits booked in foreign offices, large time deposits (with values equal or greater than $\$ 100,000$ ) and subordinated notes and debentures. 
Table 3: Summary of Conventional Mortgage Market Segment Definitions

\begin{tabular}{|c|c|c|c|}
\hline \multirow{2}{*}{ Credit Score Range } & \multicolumn{3}{|c|}{ Loan-to-Value (LTV) Range } \\
\hline & $<80$ percent & $80-90$ percent & $>90$ percent \\
\hline 660 or higher & & Near-prime & Subprime \\
\hline 581 to 659 & Near-prime & Near-prime & Subprime \\
\hline 580 or lower & Subprime & Subprime & Subprime \\
\hline
\end{tabular}




\section{Endnotes:}

1. The Basel Committee on Banking Supervision (BCBS) has proposed a more risk-sensitive Capital Accord (Basel II) that would replace the existing capital regime among G-10 and other countries. Basel Committee on Banking Supervision (June 2004). Transitional arrangements would be in place for the United States beginning in 2008. See Board of Governors of the Federal Reserve System press release "Banking Agencies Announce Revised Plan for Implementation of Basel II Framework,” September 30, 2005 (http://www.federalreserve.gov/boarddocs/press/bcreg/2005/20050930).

2. In the United States, the banking agencies have proposed that only one variant of Basel II would be permitted - the Advanced Internal Ratings Based (A-IRB) approach for credit risk and the Advanced Measurement Approach (AMA) for operational risk. See ibid. and Advance Notice of Proposed Rulemaking on Risk-Based Capital Guidelines: Implementation of New Basel Capital Accord (68 FR 45899, August 4, 2003). In the United States, the other variants of Basel II may not be used.

3. The agencies have indicated their intention to propose simple modifications to the current U.S. Basel I-based capital standards designed to make the current standards more risk sensitive - in part to address potential competitive distortions that might result from more risk-sensitive capital requirements for adopters of Basel II-based rules.

4. See, for example, Macomber (2004) and Independent Community Bankers of America (2003).

5. See, for example, Frame and White (2004a), Federal Financial Analytics, Inc. (2004), and Calem and Follain (2005).

6. A deadweight loss is a loss in social welfare deriving from a policy or action that has no corresponding gain. Deadweight losses, which represent economic inefficiency, usually result when the price-setting mechanism has some flaw. (Dictionary of Economics, 2003). In this case, the flaw is that, for some mortgages, regulatory capital requirements have resulted in an artificially high price for bearing the credit risk associated with them.

7. Calem and Follain (2005) argue that revenue gains to adopters would be less than the revenue lost by nonadopters because nonadopters lose market share and the price that they earn on their lower market share declines.

8. Depository institutions may reflect the risk-reducing effects of guarantees and credit derivatives, in support of either an individual obligation or a pool of exposures, through an adjustment to either the PD or the LGD estimate, subject to minimum requirements described in Basel Committee on Banking Supervision (2004, pp. 98-99).

9. The FRB credit risk model was calibrated to prime, fixed-rate mortgages and is described in Calem and Follain (2003). For each credit score-LTV pair, the model estimates cumulative discounted losses using paths for house prices (from the Office of Federal Housing Enterprise Oversight) and for interest rates (from Freddie Mac) over 10-year periods with a random "start quarter” during the period from 1982:Q1 to 1991:Q4. From 15,000 such paths for these variables a 
probability distribution for credit losses is constructed for each credit score-LTV pair. The 99.9 percentile of the loss rate from the resulting cumulative credit loss distribution, less the expected loss, is the estimate of economic capital.

10. In these calculations, the LTV ratios ranged from 60 to 105 in 5-unit increments, and the credit scores ranged from 500 to 800 in 20-unit increments. We applied the FRB credit risk model to the nonprime mortgage market using the methods of Calem and Follain (2003) and described in more detail in Calem and LaCour-Little (2004). In essence, loans with higher-risk are modeled as defaulting in shorter periods, resulting in larger losses because of less home equity accumulation. For examples of economic capital estimates for nonprime mortgages, see table 2 of Calem and Follain and tables 6 and 8 of Calem and LaCour-Little. The credit quality index is constructed using the fractional rankings of the economic capital estimates in descending order for the 184 credit score-LTV pairs.

11. The Basel II framework also establishes a minimum PD that can be used in the supervisory formula (equal to $0.03 \%$ ) so regulatory capital would also be higher than economic capital when the internal borrower grade is assigned a PD less than $0.03 \%$.

12. Under Basel I, each asset and the credit equivalent amounts of off-balance-sheet exposures are generally assigned to one of four broad risk categories that are based on the perceived credit risk of the obligor or, if relevant, the guarantor, type of collateral, or external ratings. These risk categories are assigned weights of 0 percent, 20 percent, 50 percent, and 100 percent and are thus associated with 0 percent, 1.6 percent, 4 percent, and 8 percent capital requirements.

13. See, for example, Calem and LaCour-Little (2004), Calem and Follain (2003), and Kaskowitz, et al. (2004).

14. There is a long literature on capital arbitrage as a motivation for securitization; see Ambrose, LaCour-Little, and Sanders (2004), DeMarzo (2004), Jones (2000), Mingo (2000), or Passmore (1994).

15. Economic capital estimates from the FRB credit risk model shown in figure 3.1 are derived using a target insolvency rate consistent with historical default rates in the range of $\mathrm{BBB}+$ to A-. Economic capital estimates based on an A rating, for example, would always be larger than those based of the range of $\mathrm{BBB}+$ to $\mathrm{A}$-. If depositories hold capital consistent with a rating better than A, then the competitive effects described below would be lower because the capital buffer over the minimum regulatory capital would be larger.

16. See Gordy (2003) for a discussion of the dependence of ratings-based capital rules on a single systematic risk factor.

17. We calculated these "stress LGDs" using historical housing market data and the FRB credit risk model described in Calem and Follain (2003). We used a three-step procedure. In the first step, we selected the fourth year after origination to represent the average age when a mortgage loan goes into default (that is, a 180-day delinquency). Expected foreclosure and loss rates were calculated for such loans, with selected credit score - LTV characteristics, using historical paths for house prices 
and interest rates. The maximum value of the conditional LGD for origination quarters during the 1986-1993 period was defined as the "historical stress-period LGD.” In the second step, we used the FRB credit risk model to estimate LGD distributions for the 184 credit score-LTV pairs with LTV ratios ranging from 60 to 105 in 5 unit increments and credit scores ranging from 500 to 800 in 20unit increments. In the third step, we mapped the historical stress period LGDs to percentiles of the estimated LGD distributions for the selected credit score - LTV pairs and assigned the remaining credit score - LTV pairs to a percentile for historical stress using linear interpolation techniques. The resulting “stress LGDs” are about 1.5 times larger than expected LGDs. Annualized probabilities of default were used for each credit score - LTV pair.

18. We have some evidence that the credit agencies engage in such behavior. As stated by Standard \& Poor's, "if a banking group were to reduce capital materially due to the anticipated change in the regulatory calculation of risk assets, without any change in the bank's current economic risk profile, it would be subject to a ratings review that could lead to a downgrade.” However, we note that rating agencies give explicit credit for future interest rate margins and other forms of credit enhancement that are not in the form of directly held capital. Thus, our estimates of prudent economic capital do not incorporate all forms of market-determined capital support. See Standard \& Poors’s (2004) and Simensen (2004).

19. A GSE meets its minimum capital level if its core capital—common stock, perpetual noncumulative preferred stock, paid-in capital, and retained earnings-equals or exceeds minimum capital. Minimum capital is 2.5 percent of assets plus 0.45 percent of adjusted off-balance-sheet obligations (OFHEO Report to Congress, 2004). Since the off-balance-sheet obligations are almost exclusively mortgage-backed securities, the 45 basis points is informally taken as the GSEs' minimum regulatory capital requirement for bearing the credit risk associated with a conforming mortgage.

20. In 1999, the equity premium was approximately 2.7 percent. Sharpe (2002) discusses the method used to calculate this estimate. The equity premium estimate for 1999 using this method is relatively low compared to that for other years; however, the technique uses a Treasury security as its benchmark, which may overstate the equity premium relative to a calculation that uses a corporate security as its benchmark.

21. This assumption is based on data from the 1999 Federal Reserve Board Survey of the Performance and Profitability of CRA-Related Lending. In this survey, depositories reported their overall return on equity for their 1-4 family mortgage lending. For the 89 depositories that reported this return, it was on average 14.1 percent. But for those that were also among the 10 largest depositories (ranked by asset size), this return was slightly above 15 percent on average.

22. This is the average yield on senior bank debt rated AA or A with maturities of at least three years issued by the largest bank holding companies.

23. See Jones and Mingo (1998).

24. The Federal Deposit Insurance Corporation Improvement Act (FDICIA) of 1991 established the system of prompt corrective actions to be taken toward troubled insured depository institutions 
(other than credit unions). Leverage ratios (i.e., capital-to-asset ratios) are used as a basis of categorizing institutions for the purposes of these actions.

25. For a detailed description of this framework, see Heuson, Passmore, and Sparks (2001).

26. Frame and White (2004b) also discuss how banks adjust to capital requirements by blending loans across the risk spectrum in their portfolios.

27. This graph is taken from Heuson, Passmore, and Sparks (2001).

28. Focusing on the portfolio decision in the absence of capital requirements, a risk-neutral mortgage originator will offer a mortgage if $q r+(1-q) r_{d} \geq r_{f}$ where $r$ is the mortgage rate received by the lender if the borrower does not default, $r_{d}$ is the expected return to the lender if the borrower does default, and $r_{f}$ is the expected return on an alternative investment. Rewriting this expression in terms of an equality and solving for $r$, it is easily demonstrated that the inverse supply function for mortgages is decreasing in $q$ and $r_{d}$, but increasing in $r_{f}$. See Heuson, Passmore, and Sparks (2001, p. 340).

29. Using the formula provided in the previous footnote, which is explained in greater detail in Heuson, Passmore, and Sparks (2001), the black line incorporates a fixed capital requirement-that may result from a risk-insensitive mortgage capital regulation or a leverage requirement-when calculating the depository's expected return on the alternative investment. In contrast, the light gray line incorporates the market's credit risk-sensitive capital requirement. This marginal cost curve with respect to credit quality implicitly assumes that other marginal costs for mortgage financing do not vary with respect to credit quality. Thus, the curvature simply reflects the effective cost of capital to back the credit risk (or an equivalent credit guarantee).

30. The securitizer may be a purely private entity, a government-sponsored agency, or an affiliate of a bank holding company. Regardless, the securitizer's marginal cost will be determined by the market's demands and conditions and the regulatory capital framework they face, if any.

31. The GSEs' mortgage-backed pools often are backed by only a small number of mortgages and are not geographically diversified (Downing, Jaffee, and Wallace, 2004). For example, as of September 2003, the average Fannie Mae MBS pooled 58 loans with a principal balance of \$8.2 million (Congressional Budget Office, 2003). However, investors are indifferent to the size and diversification of these pools because all the pools are backed by the same GSE guarantee.

32. Note that the lowest-risk mortgages retained by depositories are not necessarily conforming mortgages; indeed, some may not be conforming by design to save some costs associated with conforming mortgages. For example, some "low-doc" mortgages are made to very low-risk borrowers and, because of the lack of documentation, are not conforming mortgages.

33. For depositories that are not mortgage specialists, these higher risk credits can be other types of loans, such as small business loans. The process of blending loans of high and low risks will remain important for Basel II adopters, since they will continue to be subject to leverage requirements. Banks with a composite supervisory rating equal to one are subject to a minimum leverage ratio of 3 
percent. For lower rated institutions, however, the minimum tier 1 leverage ratio is 3 percent plus an additional cushion of at least 100 to 200 basis points.

34. Nonadopters may cede this market subsegment to adopters because there are limits to blending high-risk and low-risk mortgages, or because they do not have other high-risk loans to blend with low-risk mortgages.

35. The model presented here is a stylized version of Heuson, Passmore, and Sparks (2001). More generally, the underwriting standards of market participants - depositories and securitizers alike may change as mortgage rates change (i.e., the light gray vertical dashed lines may move to the left or to the right).

36. In contrast, in an adverse selection model (such as proposed by Stiglitz and Weiss, 1981), when mortgage rates rise lower risk borrowers drop out of the pool of potential borrowers. This type of adverse selection model assumes that borrowers with higher default risks have higher expected returns from their investment projects (in this case, the project is a home purchase). In our model, however, the benefits associated with homeownership are not related to a household's default probability. In this case, rising mortgage rates simply raise the cost of homeownership without any offsetting effects.

37. Our estimates for the mortgage market combine several primary data sources over 2001-2003. Loan quantities were gauged using 2003:Q3 sources. See footnotes for figure 4 below.

38. See Raiter and Parisi (2004) for the Standard \& Poors’ description of these classifications.

39. The strong correlation between measures of borrower creditworthiness and collateral, and default and loss rates has been established by many studies, including Avery, Bostic, Calem, and Canner (2000) and Cotterman (2004).

40. For a description of subprime lending, see Canner, Laderman, and Passmore (1999), NEC (2004), and Pennington-Cross, Yezer, and Nichols (2000). Our definitions draw a clear distinction between near-prime and subprime, whereas industry practice is to commingle these two groups. Indeed, some so-called subprime mortgage pools have high credit scores, low LTVs, and no straightforward reason for their subprime designation. Part of the difficulty in defining these markets is the wide variety of different mortgage types. In particular, the near-prime market encompasses a variety of submarkets that reflect the many different ways that underwriting can deviate from conforming loan standards, including loans that are low risk but have less documentation, that are low risk but are unusual ARM contracts, that are extended to borrowers with slightly higher than typical debt ratios, that are collateralized by condo, co-op, or investor properties, or that are extended to borrowers who have recently missed a small number of non-mortgage loan payments. The credit scores and LTV ratios may or may not capture some of this variation, making our reliance on such scores and LTV ratios for defining this market only a rough approximation.

41. In the Expanded Guidance for Subprime Lending Programs that is dated January 31, 2001, bank supervisors indicated that nonprime borrowers display a range of credit characteristics that include: (1) two or more 30-day delinquencies in the last 12 months, or one or more 60-day delinquencies in 
the last 24 months, (2) judgment, foreclosure, repossession, or charge-off in the prior 24 months, (3) bankruptcy in the last 5 years, (4) a relatively high default probability as evidenced by a credit bureau score (FICO) of 660 or below (depending on the collateral), and (5) a debt service-to-income ratio of $50 \%$ or greater, or otherwise limited ability to cover family living expenses after deducting total monthly debt-service requirements from monthly income (Federal Reserve Board, Banking Supervision and Regulation SR Letter 01-4). This supervisory guidance applies specifically to institutions that have subprime lending programs with an aggregate credit exposure greater than or equal to 25 percent of their tier 1 capital, to institutions that have experienced rapid growth or adverse performance trends, and to institutions that have inadequate or weak controls.

42. In all cases, the LTV ratio here refers to the LTV ratio calculated by the lender after accounting for risk mitigation efforts, such as private mortgage insurance.

43. In the Interagency Guidance on High LTV Residential Real Estate Lending that is dated October 8, 1999, bank supervisors stated that "first-lien mortgages or home equity loans on owner-occupied, 1- to 4- family residential property loans whose LTV ratios equal or exceed 90 percent should have appropriate credit support, such as mortgage insurance, readily marketable collateral, or other acceptable collateral” (Federal Reserve Board, Banking Supervision and Regulation SR Letter 9926). If these loans do not have appropriate credit support, then they should be identified in the institution's records, their total amount should not exceed 100 percent of the institution's total riskbased capital, and the permanent credit file should set forth the relevant credit factors (e.g., credit score or debt-to-income ratio) that justified the underwriting decision.

44. We take the aggregate mortgage debt for these types of mortgages (from the Federal Reserve's Flow of Funds accounts) and divide it by the average loan amount (using LoanPerformance Corporation data).

45. The method used to impute credit scores from Survey of Consumer Finances data is described in Barakova, Bostic, Calem, and Wachter (2003).

46. For this analysis, we adjusted the proprietary credit risk scores assigned to individuals in the national sample of credit scores to match the distribution of FICO credit history scores for which information is publicly available (see Avery, Calem, and Canner, 2004). The Survey of Consumer Finances (SCF) is used to derive the proportion of mortgage holders in each credit score - LTV category. These proportions are then adjusted to match the national distribution of credit scores and the national distribution of LTVs using a least-squares algorithm. We assume that the shares of the population in LTV cells with credit scores of less than 580 are equal because there are so few households in the SCF (and thus in the mortgage-holding population) that have such low scores.

47. These comparisons are conducted assuming that the leverage requirement on depositories does not influence adopters' decisions in mortgage markets at the margin. This assumption implies that the changes in marginal capital requirements under Basel II are important and yields calculations of larger potential effects of Basel II implementation on mortgage pricing than otherwise. If the leverage requirement influences adopters’ decisions at the margin, Basel II implementation would have smaller effects than projected. 
48. In the bottom panel of figure 2, the Basel II capital requirement is lower than the minimum capital requirement for both the nonadopters and the GSEs for borrowers with a probability of not defaulting on their loan greater than $q_{2}$. For the market segments in figure 5, this corresponds to the dark gray regions.

49. In the bottom panel of figure 2, prudent economic capital is greater than 4 percent for borrowers with a probability of not defaulting on their loan less than $q_{0}$. For market segments in figure 5, this corresponds to the light gray regions.

50. See also Gates, Perry, and Zorn (2002) as well as Cutts, Van Order, and Zorn (2001).

51. Roughly 15 to 20 percent of these mortgages carry private mortgage insurance, suggesting that the capital needs of the PMI companies also play a role in determining the total cost of the mortgage to the borrower (see Canner and Passmore, 1996). In addition, some borrowers now obtain a second mortgage to cover some or all of the down payment (so-called "80-10-10s" and "80-15-5s"). Almost all of these borrowers are prime borrowers.

52. Two basis points was derived in the following manner. Twenty basis points is the median estimated prudent capital required for prime loans (see lower left-corner of figure 5). This estimate is multiplied by 8.8 percent, which is the maximum carrying cost of capital calculated in section 2.4, yielding 1.76 basis points.

53. Ideally, one would want to subtract expected losses from net income. Fannie Mae's actual losses have been around 0.6 basis points for some time (even during the past recession). Thus, using this figure probably approximates the expected loss rather well. But to provide a conservative comparison, we will use 12 basis points (rather than 12.8 basis points) as the net income figure.

54. The equity premium for GSEs would also range between 2.7 and 8.8 percentage points and, given that the GSEs minimum capital cost is 45 basis points, their competitive capital carrying cost would range between 1.22 (i.e., 0.027•45) and 3.96 (i.e., $0.088 \bullet 45$ ) basis points.

55. Our calculations appear to be consistent with OFHEO calculations. OFHEO estimates that the average guarantee fee ranges from 20 to 24 basis points and the costs related to GSE guarantee activities range between 11 and 19 basis points. These costs include estimates of credit losses (in the 3 to 5 basis point range), administrative costs (in the 5 to 8 basis point range), and equity capital costs (in the 5 to 8 basis point range). See Inside Mortgage Finance (January 21, 2005, p. 6).

56. In the prime market, over 40 percent of ARMs are not securitized whereas about 25 percent of fixed-rate mortgages are not securitized.

57. Since some institutions are among the largest bank-holding companies and are also very active in mortgage markets, they are in more than one group. There are 26 institutions in total.

58. As discussed in Calem and LaCour-Little (2004), the use of a single risk-factor model in the Basel II framework "is a significant omission in the case of mortgages." For subprime mortgages in 
particular, the internal ratings-based approach may be limited by the use of a single systematic risk factor (as discussed in Gordy (2003)), thereby perpetuating regulatory capital arbitrage.

59. In addition, the models used by adopters may be more conservative than the FRB model. See, for example, Kupiec (2005).

60. In fact, Edelberg (2003) uses data from Surveys of Consumer Finances (1983-1998) and data on bankruptcy from the Michigan Panel Study of Income Dynamics to provide evidence that lenders have increasingly used risk-based pricing of interest rates in mortgage markets as data storage costs have fallen and underwriting technologies have improved.

61. In contrast, “undercapitalized” depositories have a tier 1 risk-based capital ratio under 4 percent, a total risk-based capital ratio under 8 percent, or a tier 1 leverage ratio under 4 percent (3 percent for most depositories that have a composite supervisory rating equal to one).

62. As indicated above, banks with a supervisory rating equal to one are subject to a minimum leverage ratio of 3 percent. For lower-rated institutions, however, the minimum tier 1 leverage ratio is 3 percent plus an additional cushion of at least 100 to 200 basis points. 